GEOLOGICAL SURVEY CIRCULAR 133

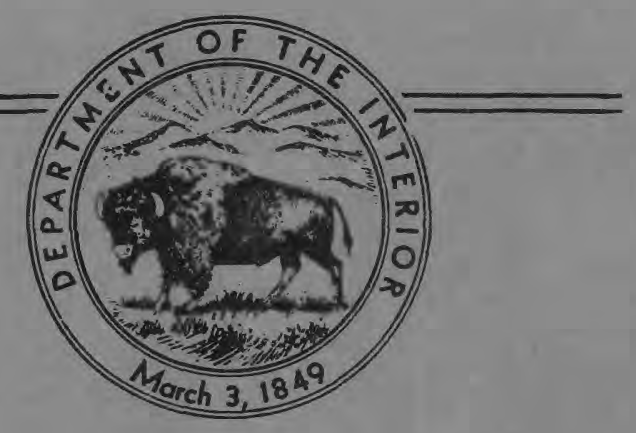

\title{
DETROIT RIVER GROUP IN THE MICHIGAN BASIN
}

\section{By}

Kenneth K. Landes 


\section{UNITED STATES DEPARTMENT OF THE INTERIOR \\ Oscar L. Chapman, Secretary \\ GE OLOGICAL SURVEY \\ W. E. Wrather, Director}

Washington, D. C.

\footnotetext{
Free on application to the Geological Survey, Washington 25, D. C.
} 


\section{CONT ENTS}

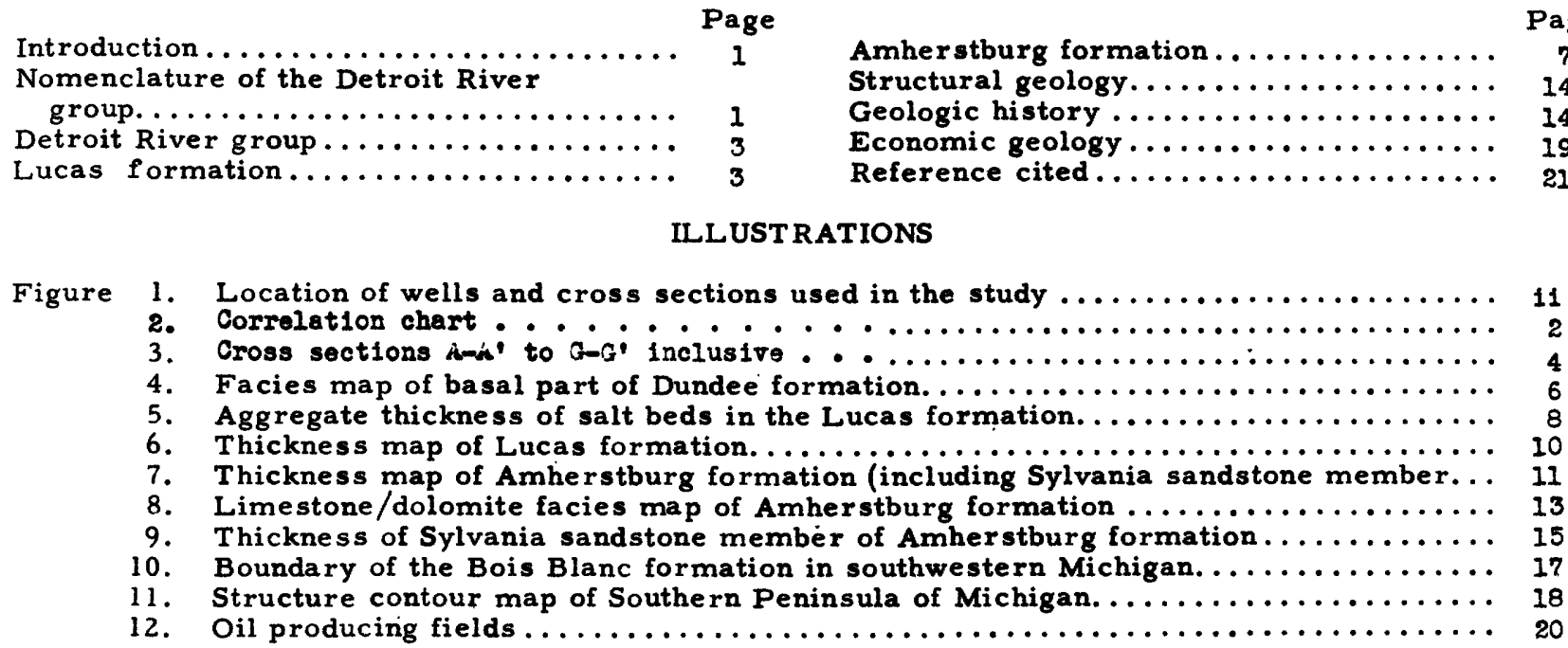

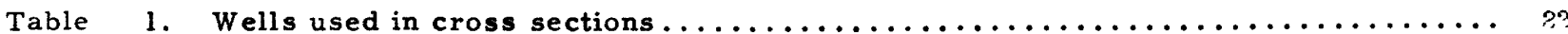




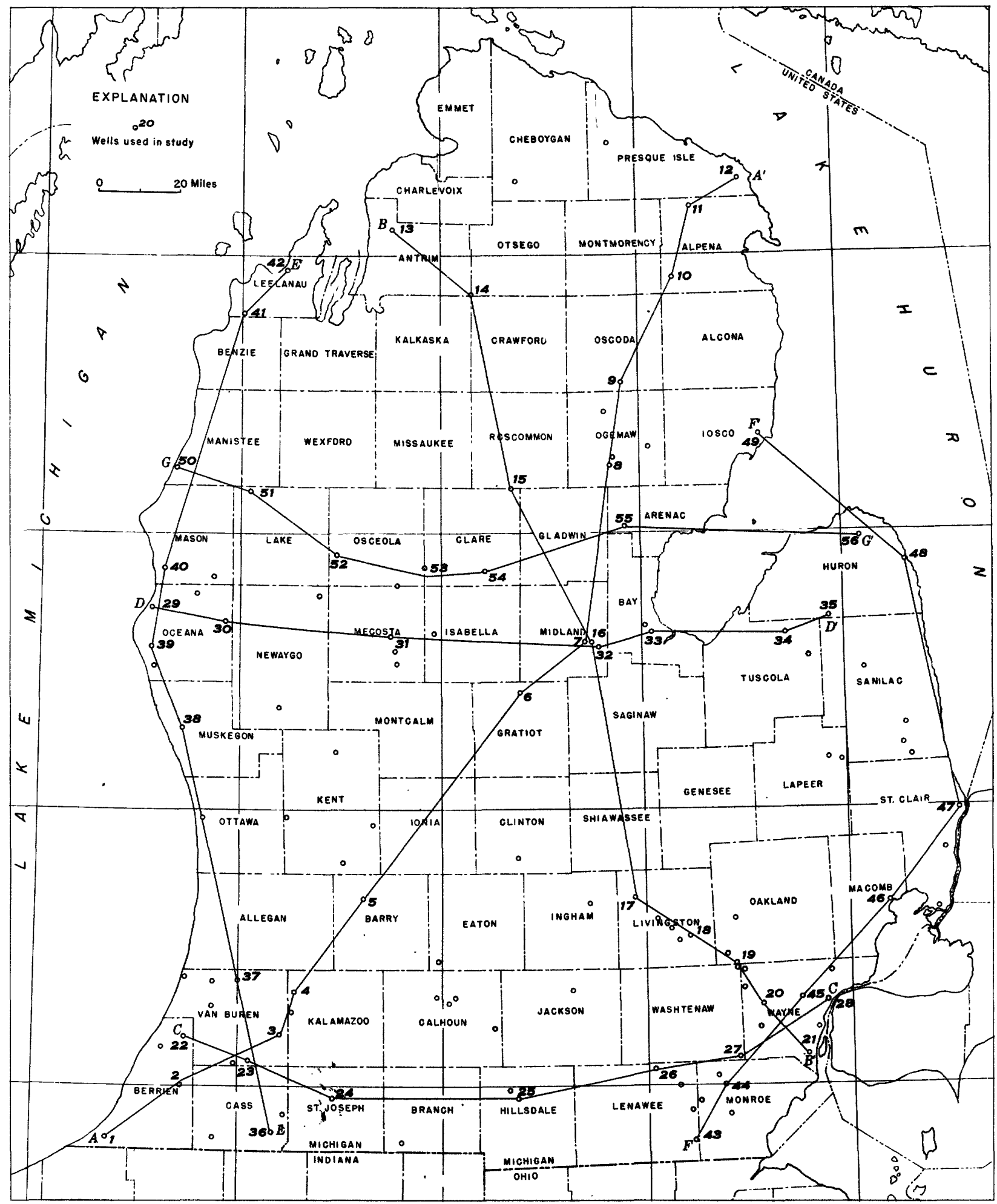

Figure 1. Index map showing location of cross sections and location of wells used in the study. 


\section{DETROIT RIVER GROUP IN THE MICHIGAN BASIN}

By

Kenneth K. Landes

\section{INTRODUCTION}

This report attempts to correlate the outc ropping rocks in the type locality of the Detroit River group with the thick sequence of rocks that has been explored by many drilled wells in the Michigan Basin during the last twenty years. The surface nomenclature as recently revised(Ehlers, 1950 ) is suggested for the subsurface section in place of the heterogeneous collection of names now used. The present work revises earlier re ports by the writer $(1945, a, b, c)$.

During the preparation of this report the samples have been examined from more than 300 wells and cores from 9 wells. The writer has also drawn upon the work of Enyert (1949) who wrote a Doctoral thesis on the sandstones of the Detroit River group, and upon Master's theses on various phases of Detroit River stratigraphy written by Cooley (1947), Saunders (1948), and Tharp (1944). Finally the writer has had the advantage of many consultations in office and field with George V. Cohee of the U. S. Geological Survey, Professors G. M. Ehlers and E. C. Stumm of the University of Michigan, and with other geologists of Michigan and Ontario, especially George D. Lindberg (Sun Oil Company, Toledo), E. J. Baltrusaitis and K. A. Gravelle (Gulf Refining Company, Saginaw), Willard A. Sanger (Pure Oil Company, Clare), Joseph Lindsay and George Winston (Carter Oil Co., Grand Rapids), and Charles S. Evans (Union Gas Co., Chatham, Ontario). It is a pleasure to acknowledge the help received from these geologists and to thank them for it.

The surface and subsurface sections through the Detroit River $\mathbf{g r o u p}$ in Canada are not included in this report.

\section{NOMENCLATURE OF THE DETROIT RIVER GROUP}

The lengthy and somewhat complicated history of Detroit River group ( $1 \mathrm{~g} .2)$ will not be repeated here. The Detroit River group which formerly was considered as Lower Devonian is now placed in the Middle Devonian on the basis of recent paleontologic studies. The principal outcrop area of Detroit River is in and near the type locality between Detroit and Monroe, Michigan, and in the vicinity of Sylvania, Ohio. The most quoted classification of the Detroit River group is that proposed by Lane, Prosser, Sherzer, and Grabau (1909). They divided the Detroit River ("Upper Monroe") group into the Lucas, Amherstburg, Anderdon, and Flat Rock formations in descending order. Subsequent experience and observation have verified the validity of the Lucas and Amherstburg formations. The Flat Rock, however, does not merit formation status. At its type locality in the town of Flat Rock a bed of carbonate rock two or three feet in thickness is poorly exposed in the channel of the Huron River. This section has not been identified with certainty anywhere else; furthermore it is the opinion of $G$. $M$. Ehlers and the writer, based on geographic and structural position of the outcropping strata at Flat Rock that these strata actually belong within the Lucas formation. The Anderdon limestone as described by Lane and others was likewise misplaced in the stratigraphic section in the opinion of Ehlers (1950). This formation, which has a distinctive fauna, actually lies above the Lucas at the top of the Detroit River group in the type area.

The writer places the Sylvania sandstone within the Detroit River group, and considers it to be a member of the Amherstburg formation because of the general transition between the sandstone an'd the overlying limestone or dolomite of the Amherstburg formation in the outc rop and in well samples. Carman (1936) believes that the Sylvania was deposited in a transgressing sea so that the sandstone extends across age boundaries within the Detroit River group and is the refore of variable age.

Although many geologists have studied the Detroit River group in the subsurface, few have published the results of their work. Local descriptions are included in various oil field reports. Newcombe (1933) appears to have been the first to publish a description of the Detroit River of the Michigan Basin on a regional scale. He had recognized earlier the existence of salt beds in the Detroit River group as well as in the Salina (1929). The Detroit River of northern Michigan was described by Landes (1945, pp. 168-174). A committee of the Michigan Geological Society (George V. Cohee and Helen M. 


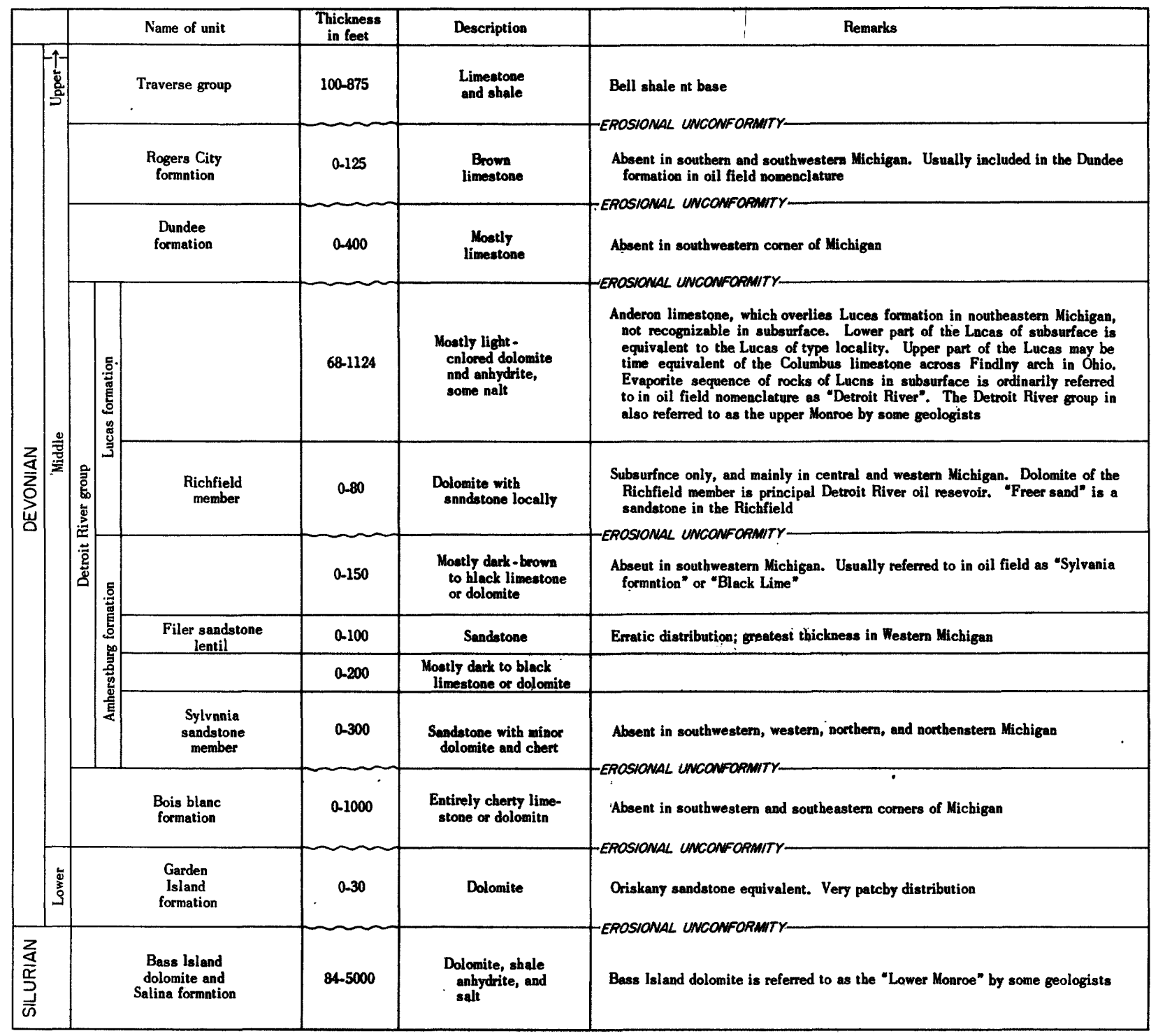

\section{Figure 2. Proposed ncmenclature for a part of the subsurface section of the Michlgan basin.}


Martin, editors) issued a multigraphed report in 1948 on a "A Summary of the Stratigraphy of the Southern Peninsula of Michigan" in which the subsurface Detroit River rocks are discussed.

The general practice of geologists in describing the subsurface stratigraphic section in the Michigan Basin between the Dundee formation and the Bass Island and Salina formations is to refer to the evaporite sequence of rocks within the Detroit $R$ iver group as the "Detroit River" and the underlying carbonate rocks as the "Sylvania formation" which overlies the "Sylvania sandstone" where present.

\section{DETROIT RIVER GROUP}

The Detroit River group, which extends throughout the Southern Peninsula of Michigan in the subsurface, is principally a sequence of dolomite, anhydrite, (and salt in the northern half of the Southern Peninsula), dark brown to black limestone and sandstone. In the subsurface the Detroit River group is overlain by the Dundee formation of Middle Devonian age except in southwestern Michigan where the Dundee is absent (fig. 4). The Detroit River group overlies the Bois Blanc formation also of Middle Devonian age except in western and southern Michigan where it overlies rocks of Silurian age (fig. 10$)$.

The subdivisions of the Detroit River group in the Michigan Basin are given in the accompanying stratigraphic chart. Overlying and underlying units are also shown. The Anderdon limestone is omitted from the subsurface stratigraphic section because it has not been identified anywhere in the subsurface except at the Detroit salt mine which is less than eight miles from the outcrop.

\section{LUCAS FORMATION}

The Lucas dolomite has been redefined by Ehlers (1950) as a formation in the upper part of the Detroit River group of Middle Devonian age. It is underlain by the Amherstburg dolomite of the Detroit River group and in the outcrop area is overlain by the Anderdon limestone. The dolomite of the Lucas contains fossils diagnostic of Middle Devonian age. In order to apply the outcrop terminology so far as possible to the sediments of the central part of the Michigan Basin, the Lucas is defined as a formation in this report that includes the thick evaporite sequence which overlies the dolomite sequence, (Richfield member) down dip from the outcrop area.

The Lucas formation in the central part of the Michigan Basin consists of beds of Dolomite, anhydrite, salt, limestone, and sandstone, in order of decreasing abundance. Some of the carbonate rock layers are argillaceous, but otherwise shale is conspicuously absent. The formation thickens from a minimum of $18 \mathrm{ft}$ in a well in Berrien County (well 1, cross section A-A', 19. 3) in the southwestern corner of the State to about $1,000 \mathrm{ft}$ in Clare County (well 33, cross section G-G', 118. 3). In all cross sections the datum plane is the
Dundee-Detroit River contact. In Michigan the Lucas formation crops out only in the southeastern part of the State, along the Detroit River a short distance south and southwest of the city of Detroit. It crops out across the river in southwestern Ontario, and is also exposed in Lucas County and other parts of northern Ohio. The lower part of the Lucas in the central basin area appears to correlate with the Anderdon and Lucas sequence of rocks in the outcrop. This relationship is shown in the accompanying cross sections, especially B-B' (11B. 3). The light color of the dolomite and the presence of nodules of anhydrite in the outcropping Lucas tend to support this correlation, but the best evidence to date has been the discovery of the fossil Prosserellas of the type characteristic of the Lucas in cores from the State-Mancelona A-1 well in the southeastern corner of Antrim County (well 14, cross section B-B', 11g. 3) E. C. Stumm, verbal communication, July 27,1950 . The upper part of the Lucas in the central part of the basin, which includes the beds of salt, was deposited in a sea of concentrated brine which had shrunk to such an extent that it no longer covered the present outcrop area. Ehlers (oral communication) has proposed the plausible theory that during this time of salt and evaporite deposition in the central part of the basin, and of no deposition higher on the basin flanks, the Columbus limestone was being deposited in normal marine waters farther southeast across the axis of the Findlay arch. The Columbus limestone, which is widespread in central and northern Ohio, but has never been recognized on the Michigan Basin side of the Findlay arch, Stumm, (oral communication) directly underlies the Delaware limestone. The Delaware has been correlated (Cooper and others, 1942) with the Dundee formation of Michigan which overlies the Lucas.

Because the basal part of Dundee formation is limestone or dolomite and the upper part of the Lucas formation is also limestone or dolomite in most places it is not always possible to ascertain the exact position of the contact of the two formations. Furthermore, the task is complicated by an erosional unconformity at the top of the Detroit River group that cuts out certain beds within relatively short distances due to differences in the level of erosion. As fossils are not available in most cuttings the determination of the contact in wells must be based on lithologic differences. The following criteria are useful in various parts of the Michigan Basin: sand in the basal part of the Dundee; chert in the lower part of the Dundee; limestone in the Dundee; darker color of carbonate rock in the basal part of the Dundee; dolomite in the Lucas; and anhydrite in the Lucas. Unfortunately, none of these criteria is unfailing. In many of the.cutting $s$ of the Dundee formation in wells drilled in 
Michigan both sand 8 rains and chert are absent, and every one of the other criteria is subject to exception.

The Dundee formation is absent in Berrien and western Van Buren Counties in the southwestern part of the State, where rocks of the Traverse group directly overlie the Lucas formation, but it is present elsewhere in the Michigan Basin. The Dundee formation contains a basal sandstone on the southeast flank of the basin in parts of the southwestern Ontario peninsula. Sand grains are abundant in the basal part of the Dundee in wells drilled in southeastern Michigan in western Wayne and northeastern Washtenaw Counties. Sand grains were also observed in cuttings of basal part of the Dundee in individual wells drilled in ten other counties in an area extending from Antrim to Lenawee and from Oceana to Huron Counties. Chert was found in the basal part of the Dundee in samples from 13 wells scattered over 6 counties, all in the southeastern quadrant of the Southern Peninsula. Beyond the area in southwestern Michigan where the Traverse group overlies the Detroit River $\mathbf{g r o u p}$, the identification of the top of the Lucas is most positive where sand $g$ rains or chert are present in the basal part of the Dundee.

Generally, the carbonate rocks in the Dundee formation is limestone and that in the Lucas formation is dolomite, but there are numerous exceptions. In many localities the lowermost beds of the Dundee are dolomitic, perhaps due to replacement activity by circulating ground waters which picked up magnesium salts in the underlying dolomite of the Lucas. A facies map of the basal part of the Dundee (fig. 4) shows three major and at least five minor areas of dolomite in the Southern Peninsula. The major areas are: (1) southeast of Leelanau and Benzie Counties into Clare and Isabella Counties; (2) Livingston County and northeast into Tuscola and Sanilac Counties; and (3) Cass County and east-northeast into Jackson County. The minor areas are scattered over other parts of the State except in the northeast part of the Southern Peninsula. The basal part of the Dundee is dolomite over about 40 percent of the area of the Michigan Basin and limestone over about 60 percent of the area.

The uppermost part of the Lucas formation is limestone in an area immediately south of the head of Saginaw Bay, and in a few other restricted areas. These areas are apparently patches of rock which, like the Anderdon limestone of the outcrop area have never been dolomitized. Where the top of the Lucas is limestone the overlying Dundee is also limestone.

Calcium sulfate, occuring mostly as anhydrite, is present within a few feet of the top of the Lucas formation almost everywhere in the Michigan Basin. The outstanding exception is near the outcrop area in southeastern Michigan, especially in
Lenawee and Monroe Counties, where anhydrite is either absent or occurs in disseminated nodules instead of in sedimentary layers. In such areas the contact of the Dundee formation and Detroit River group is usually identifiable by the presence of sand, chert, or limestone in the basal part of the Dundee. Scattered grains of anhydrite were found among samples of the Dundee in a few sets of cuttings. These grains may be cavings from beds of anhydrite in younger formations, but also may be indigenous, the result of local saturation of the sea with calcium sulfate during Dundee time.

In most sections the contact of the Dundee formation and Detroit River group is marked by a change in color of the rocks. As a general rule the lowermost carbonate rocks of the Dundee are darker than the uppermost part of the Lucas strata, owing in part, but no entirely, to the lightening effect of the scattered anhydrite $g$ rains usually present in the drill cuttings of the Lucas. In few places the Dundee above the contact is lighter than underlying Detroit River. In southeastern Michigan this is due to the presence of scattered light-colored grains of chert or sand in the Dundee.

Insouluble residues have been used to determine the contact of the Dundee formation and Detroit River group by Cooley (1947) and Saunders (1948) in and near the outcrop area, and by Wellman (1937) on well samples from the basin area. Wellman found that chert is the most abundant insoluble residue in the basal part of the Dundee formation and anhydrite the principal insoluble residue in the Detroit River group. Cooley and Saunders found relatively abundant sand grains in the basal part of the Dundee at the outc rop and in drill cuttings and one core from nearby wells. Clay and silt were the principal residues below the contact.

The carbonate rock in the Lucas formation is practically all dolomite except in the following three districts whe re an appreciable amount of limestone is also present; (1) southeastern + Michigan including most of Monroe County.and contiguous parts of Lenawee, Washtenaw, and Wayne Counties; (2) the "Thumb" and Saginaw Bay coastal area from St. Clair to Iosco County, with the northern end extending westward as far as southeastern Crawford County; and (3) the 9 tiers of townships at the northern end of the Southern Peninsula.

In most areas the carbonate rock interbedded with the evaporites in the Lucas formation is light colored, but at places in the central part of the basin a dark-brown dolomite may occur in the lower part of the unit. In some wells this brown dolomite has been mistaken for the "Black Lime" in the underlying Amherstburg formation, leading to the abandoment of wells some distance above the top of the Richfield 


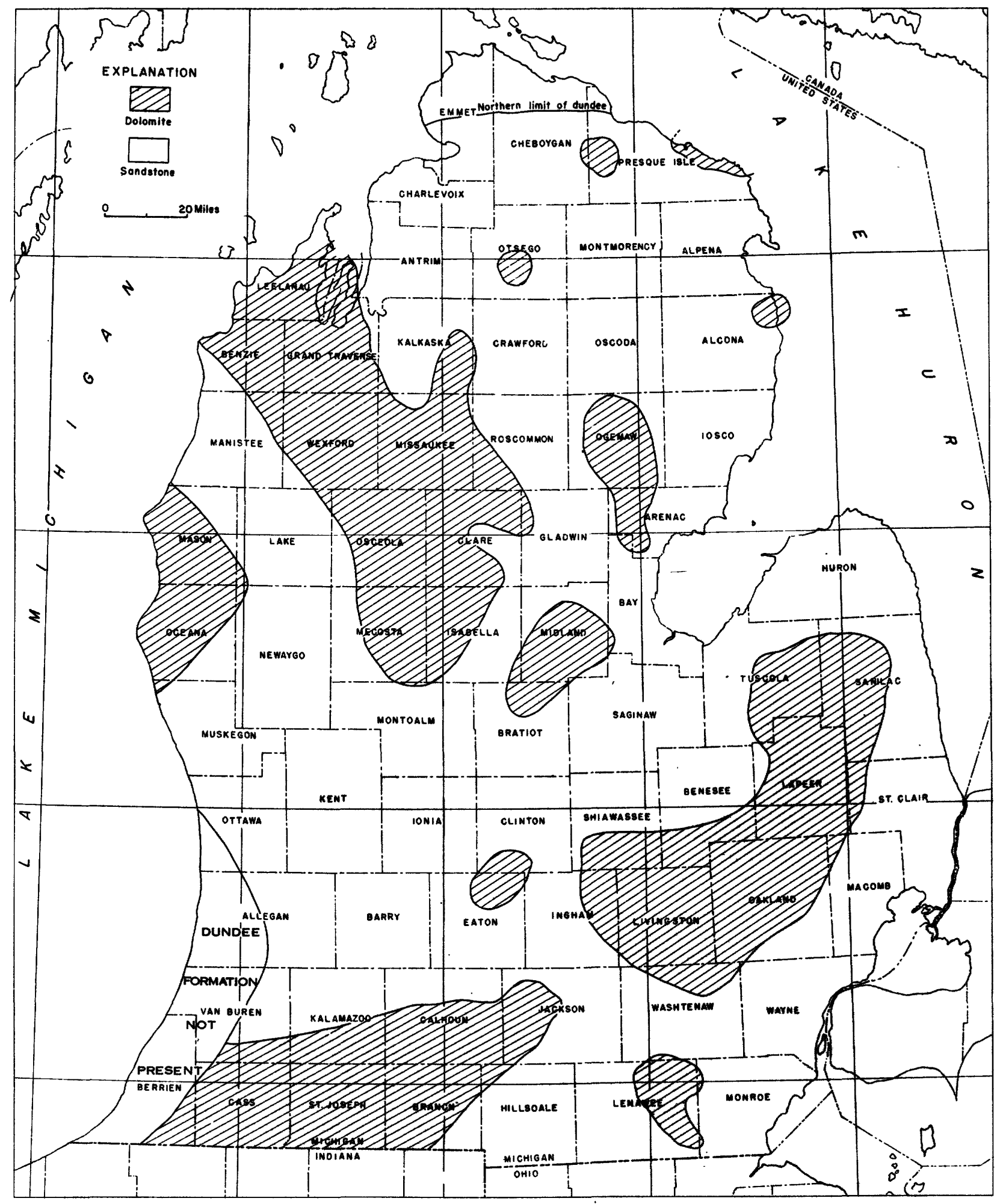

Figure 4. Facies map of basal part of Dundee formation. In ruled areas, beds are dolomite; elsewhere they are limestone. 
member which was supposed to have been tested.

The evaporites in the Lucas formation consist mainly of anhydrite and salt. Anhydrite is much more widely distributed, both vertically within the formation and laterally across the basin. The salt is confined to the upper half of the evaporite sequence and to the central part of the basin. Figure 5, modified from Tharp (1944) shows the estimated aggregate thickness of salt beds of the Detroit River group. A comparison of this map with the thickness map for the entire Lucas formation (fig. 6) shows that all of the salt lies within the $500 \mathrm{ft}$ thickness line of the Lucas, the $200 \mathrm{ft}$ thickness line of the salt is within the $750 \mathrm{ft}$ thickness line of the Lucas, and most of the salt having an aggregate thickness exceeding $400 \mathrm{ft}$ is confined to the deepest part of the basin in Missaukee and Roscommon Counties where the Lucas is more than 1, $000 \mathrm{ft}$ thick. There may be as many as $8 \mathrm{dis}$ tinct salt beds, and the thickest bed may exceed $100 \mathrm{ft}$ in thickness. The writer has presented elsewhere the theory that these salt beds resulted from the leaching and reprecipitation of salt from Salina formation of late Silurian age salt. (1945, pp. 147 149).

Generally the anhydrite increases in abundance basinward. Not only is the anhydrite-bearing sequence of rocks thicker toward the center of the evaporite basin, but also the precentage of anhydrite in any one zone increases basinward. Anhydrite occurs (1) above the salt in the center of the basin, (2) interstratified with the salt and (3) in greatest volume in the lower half of the evaporite sequence below the salt beds. The anhydrite occurs in many distinct layers, some of which attain considerable thickness. Outside the salt area anhydrite continues to be fairly abundant in the Lucas to points near the rim of the basin. The decrease in percentage of anhydrite is greatest on the north flank of the basin and toward the outcrop area on the southeast flank where beds of anhydrite are absent, but the mineral may still be present in scattered nodules.

The Richfield member is a new term applied to the porous dolomite at the base of the Lucas formation. The Richfield member is named after Richfield (now AuSable) Township in northern Roscommon County where oil was first found at this stratigraphic level. At the "type locality", the Richfield member is a porous dolomite and almost everywhere it is productive of oil. However, in the center of the Michigan Basin and on the west flank, the Richfield contains beds of sandstone. This sandstone has also been called the "Freer sandstone" after the Freer Well (well 53, cross section G-G', 1ig. 3) in southwestern Clare County. The Richfield is a distinct lithologic unit beneath the anhydrite of the Lucas formation and is here given member status. A discussion of the "Richfield zone" oil and gas reservoir is included in the section on Economic Geology.
Cross sections D-D', E-E' and G-G' 1 ig.3) show the sandstone of the Richfield member on the western flank of the Michigan Basin. According to the thickness map compiled by Enyert (1949) this sandstone extends from beneath Lake Michigan eastward across a belt about three counties wide slightly beyond Roscommon County on the north and across Midland County on the south. It is more than $50 \mathrm{ft}$ thick in a much narrower belt including parts of Mason, Lake, and Osceola Counties and extending into western Clare County. Beyond the limits of the sandstone itself, however, scattered sand grains commonly occur in the basal strata of the Lucas formation. Within the area of the sandstone its thickness is very erratic and it may be entirely absent locally. The Freer well, for example, penetrated more than $50 \mathrm{ft}$ of sandstone in which gas and distillate were ob$t$ ained, but two of the four offset wells found no sand at equivalent depths. Enyert describes a similar sandless area in south central Clare County.

\section{Amherstburg formation}

The Amherstburg dolomite as defined by Ehlers (1950) includes the beds lying between the Sylvania sandstone and the Lucas dolomite. The Amherstburg is here redefined to include the Sylvania where present, as the basal sandstone mem ber of the formation. The Filer sandstone lentil of the Amherstburg, as defined and described in this paper, occurs within the carbonate rock sequence of the formation and is confined for the most part to the western flank of the basin. Except for the Sylvania and Filer sandstone members the Amherstburg is a limestone or a dolomite. The only evaporites within the formation are occasional nodules of anhydrite observed in cores from wells drilled in the basin.

The beds assigned to Amherstburg formation in the central part of the basin agree with the fauna, stratigraphic position, and lithologic character of the Amherstburg at its type locality. Cores have been obtained from wells in the basin that contain Amherstburg fossils. Most of the Fossils are in limestone layers, but some are in the Sylvania sandstone member. The noncherty limestone or dolomite beneath the evaporites and above the cherty Bois Blanc formation on the north flank of the Michigan Basin, and heretofore described by the writer (1945a) as upper part of the Bois Blanc, is now considered to be Amherstburg.

The Amherstburg formation is a gray to brown dolomite at the outcrop in southeast Michigan and northwest Ohio. It has been studied in the rock cuts of the Livingstone channel of the Detroit River west of the town of Amherstburg on the Canadian shore, in the 


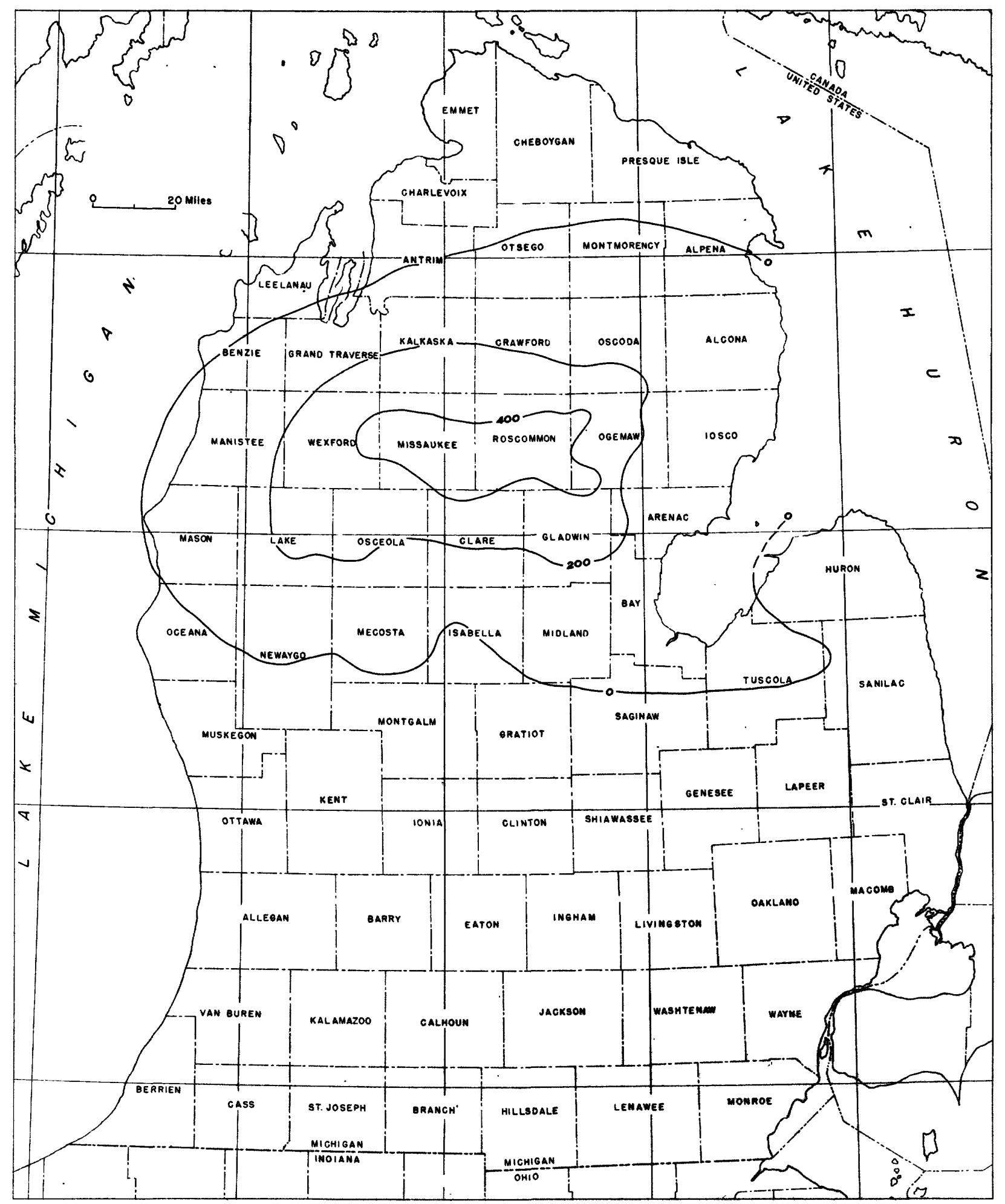

Figure 5. Aggregate thickness of salt beds in the Lucas formation. 
abandoned Cummins' quarry in southwestern Wayne County, Michigan, and in several of the quarries west and southwest of Sylvania, Ohio. The Sylvania sandstone member is exploited in a large quarry near Rockwood in southwestern Wayne County and is exposed in the floor of the Cummins' quarry and in several other abandoned quarries in southeastern Michigan and in the Sylvania district of Ohio. The Filer sandstone lentil is not exposed at the surface, but it might possibly crop out in places where it is covered by the water of Lake Michigan. Smaller exposures of lower part of the Detroit River group, probably belonging in the Amherstburg, occur near the northern tip of the Southern Peninsula and in some of the islands offshore in Lake Michigan (Ehlers, 1945).

The Amherstburg formation is present everywhere beneath the surface in the Southern Peninsula except in the southeastern and southwestern corners. Its absence in the southeastern corner is due to removal by erosion. It has been stripped off and the underlying Bass Island dolomite exposed in eastern and southern Monroe County. In southwestern Michigan its absence is due to erosion prior to the deposition of the Lueas formation which overlaps the Amherstburg. All or parts of ten counties in the southwestern corner of the State are beyond the zero line on the thickness map of the Amherstburg. (fig. 7).

The greatest accumulation of Amherstburg formation is between southern Bay and southern Roscommon Counties where its thickness exceeds $600 \mathrm{ft}$ in places. About half of this thickness is the Sylvania sandstone member at the base of the formation, which attains its maximum thickness in this area.

The top of the Amherstburg formation can be identified in the subsurface by its lithology. The light-colored, anhydrite-rich, mostly nonfossiliferous dolomites of the Lucas formation are succeeded downward by brown to black fossiliferous carbonate rocks which are limestone more often than dolomite. Furthermore the basal rocks of the Lucas tend to be sandy and the uppermost part of the Amherstburg is not. The studies of insoluble residues by Cooley (1947) and Saunders (1948) showed unsuspected amounts of sand at the stratigraphic position of the Richfield member of the Lucas in the outc rop and well samples in southeastern Michigan some distance from the area where the sandstone of the Richfield is present.

Except for local eandstones the Amherstburg formation is composed of limestone with local subordinate amounts of dolomite in the northern and eastern parts of the Southern Peninsula of Michigan. In the western and southern parts of the Southern Peninsula the Amherstburg is dolomite except in the southwestern corner where it is absent. The line separating the predominantly limestone facies from the dolomitic facies of the Amherstburg (fig. 8) starts at the south end of West Grand Traverse
Bay and extends southward to the Lake-Newaygo County line, thence eastward to the southeast corner of Osceola County, southeastward across Isabella County into northern Gratiot, eastward along the north edge of Township 12 North to the northeast corner of Saginaw County, and southeastward to the International Boundary opposite downtown Detroit.

The outstanding characteristic of the carbonate rock in the Amherstburg formation is its relatively dark color. The Amherstburg at the outcrop is generally darker than the overlying Lucas formation. In wells north and northwest of the outcrop area much of the Amherstburg is dark-brown and even black--a color change emphasized by the difference from the over1 ying light-colored evaporites of the Lucas. The Amherstburg has therefore been referred to by many geologists as the "Black Lime". The upper boundary of the "Black Lime" is readily recognized in cores and most drill cuttings, but in many sections the rock becomes lighter downward and a lower boundary cannot be fixed with certainty.

Because of gradually diminishing sand deposition the Sylvania sandstone member, where present, grades upward into the carbonate rocks without a sharp break in most places, both below the surface and at the outcrop. It is the refore impossible to map accurately the thickness of the carbonate sequence above the Sylvania. A map based on approximate thicknesses shows that these rocks are thickest between Tuscola and Roscommon Counties where the carbonate rocks alone exceed $300 \mathrm{ft}$ in thickness. A part of this area of maximum carbonate rock thickness lies northeast of the northeastern edge of Sylvania sand deposition. In.one area only, Hillsdale County in southern Michigan, the Sylvania sandstone member is not overlain by carbonate rocks of the Amherstburg. This relationship is shown in cross section C-C' (fig. 3, well 25) where Lucas formation rests directly on the Sylvania sandstone member of the Amherstburg.

The Filer sandstone lentil of the Amherstburg formation has been described in some detail by Enyert (1949). The type section for this member, which does not crop out, is the Ruggles and Rademacher well 24, sec. 12, $T$. 21 N., R. 17 W., Filer Township, Manistee County. The Filer sandstone lentil lies within the carbonate rock sequence below the Lucas formation and above the Sylvania sandstone member of Amherstburg. It is largely confined to a belt crossing the basin from Saginaw Bay to Lake Michigan. According to the thickness map compiled by Enyert, the area of the Filer sandstone lentil includes most or all of Bay, Ogemaw, Midland, Gladwin, Isabella, Clare, Mecosta, Osceola, Lake, Mason, Manistee, 


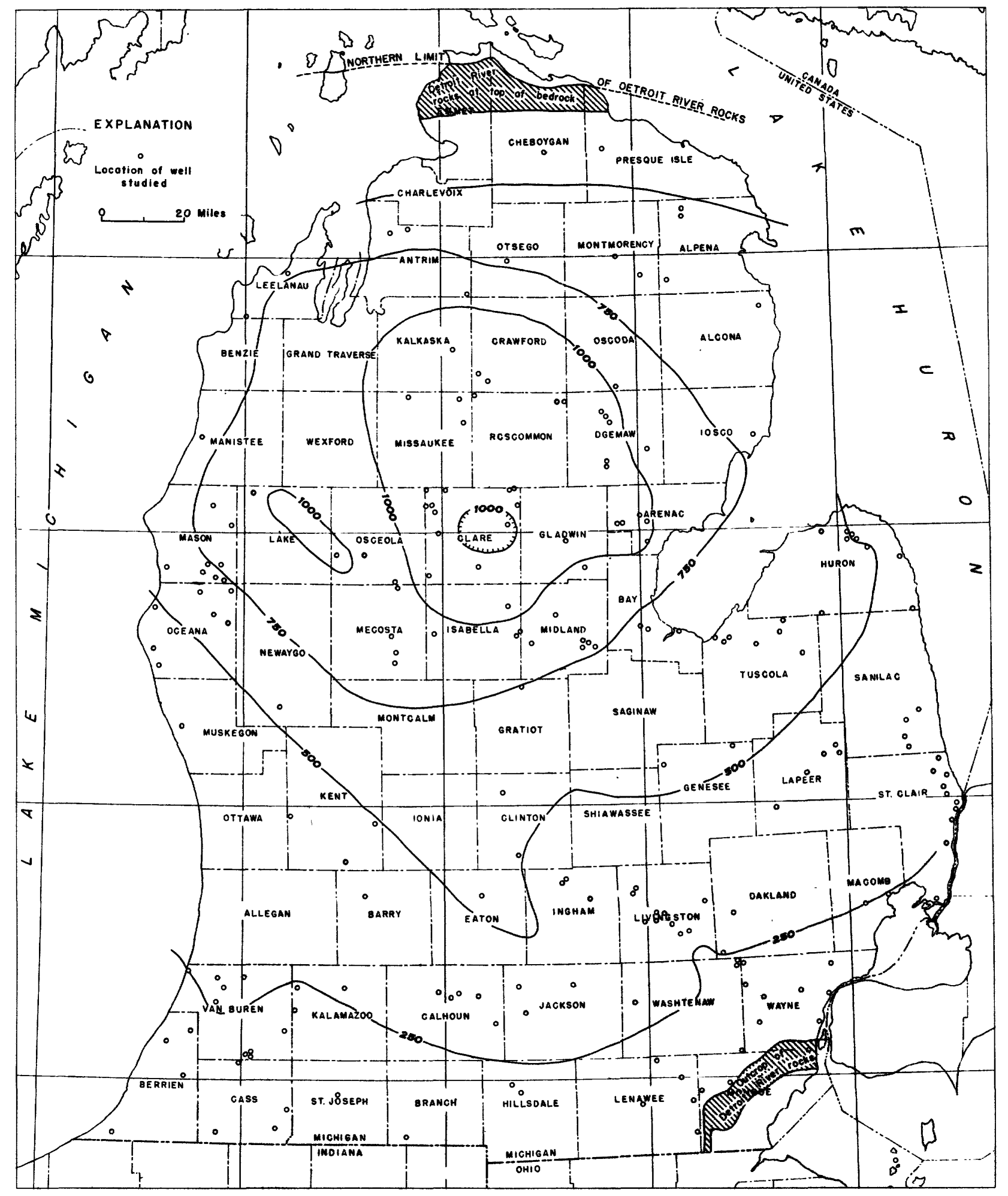

Figure 6. Thickness map of Lucas formation. 


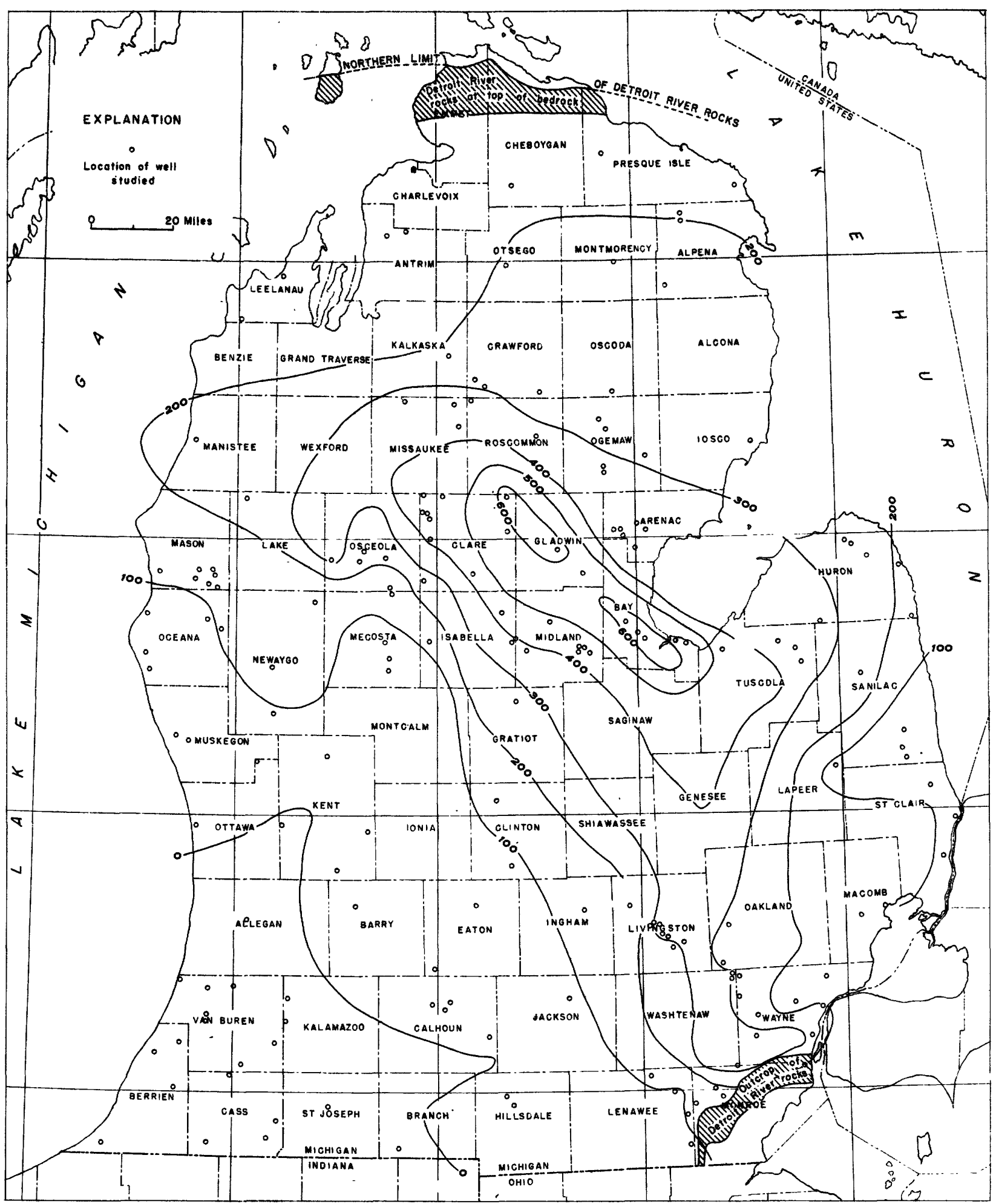

Figure 7. Thickness map of Amherstburg formation (including Sylvania sandstone member). 
and Benzie Counties. It exceeds $50 \mathrm{ft}$ in thickness in Bay and western Manistee Counties. According to R. A. Newcombe (verbal communication, July $27,1950)$ recent wells in western Michigan have penetrated as much as $100 \mathrm{ft}$ of Filer sandstone. The position of this sandstone within the Amherstburg is shown in cross sections $A-A^{\prime}, D-D^{\prime}$, and E-E' (See fig. 3). The stray sandstone above the Sylvania in the Amherstburg penetrated by a well near the northeast corner of Washtenaw County (well 19, cross section $B-B^{\prime}$ ) may also be of Filer age.

The Sylvania sandstone member of the Amherstburg formation has been described by Grabau and Sherzer (1910), Carman (1936), and Enyert (1949). Enyert studied both outcrop and subsurface sections; the others confined their investigations to the outcrop. The Sylvania sandstone is redefined in this paper as a member of the Amherstburg formation because of the upward gradation of the sandstone into the overlying carbonate rock. This absence of a sharp contact can be observed in both quarry exposures and in well samples. Carman (1936) called attention to the upward gradation of the Sylvania in 1936.

The accompanying thickness map (fig. 9) shows that the Sylvania sandstone member is limited in its distribution in the subsurface rocks in Michigan to a belt extending from Macomb-WayneMonroe-Lenawee-Hillsdale Counties in southeastern Michigan north and northwest to a probable terminus in Crawford-Kalkaska-Wexford-Lake Counties. An earlier map published by the writer (1945a) showed the Sylvania continuing westward beneath Lake Michigan, but this was based in part upon not recognizing the Filer sandstone lentil as a separate member and in part upon the interpretation of "Sylvania" in the driller's log of a well in western Manistee County (Rogers well 1, sec. $34, T .23$ N., R. $16 \mathrm{~W}$ ) as indicating the presence of sand about $140 \mathrm{ft}$ below the Filer. The presence of sand at that stratigraphic position has been questioned by Lindsay (oral communication), and until positive evidence of the presence of Sylvania sandstone member in western Michigan is obtained, the western boundary of the Sylvania is terminated as shown in figure 9 . The Sylvania sandstone member thins westward from a maximum thickness of more than $300 \mathrm{ft}$ in eastern Clare County. South of Saginaw Bay and in eastern Livingston and southeastern Washtenaw County the Sylvania exceeds $300 \mathrm{ft}$ in thickness in three other areas. The variations in sandstone thickness, and the relationship between the Sylvania and the overlying rocks of the Amherstburg and the underlying Bois Blanc or Bass Island formations are shown in the accompanying cross sections (See fig. 3). The Sylvania member appears in all cross sections except E-E' which extends along the western side of the Southern Peninsula. In some areas the Sylvania is entirely sandstone, but in other places, including the Rockwood quarry, the sandstone sequence is broken by one or more beds of carbonate rock which may or may not be cherty.
The Detroit River $\mathrm{g}$ roup is underlain by either Bois Blanc or Bass Island formations. The pre-Detroit River areal geologic map is shown in figure 10. Wells in all parts of the Southern Peninsula except those on the southwest flank of the basin, where the strata rise toward the axis of the Kankakee arch, penetrated Bois Blanc beds below the Detroit River group. In southwestern Michigan the Bois Blanc was eroded from the arch and Detroit River group directly overlie the Bass Island dolomite which underlie the Bois Blanc farther north. This relationship is shown in cross sections $A-A^{\prime}, C-C^{\prime}, D-D^{\prime}$, and $E-E^{\prime}$ (Ses fig. 3).

To date Garden Island formation, which is at the base of the Devonian sequence of rocks underlying Bois Blanc dolomite and overlying the Bass Island and Salina formations of Silurian age, has been identified definitely in in the samples only from one well, the Sun Oil Company's State-Mancelona A-1 in sec. 36, T. 29 N., R. $5 \mathrm{~W}$., in the southeastern corner of Antrim County. The core from this well contained, at depths of 4,409 to 4,411 ft unmistakable specimens of the brachiopods Rensselaria elongata (Conrad), and Costispirifer arenosus (Conrad), typical guide fossils of the Oriskany sandstone. These fossils are also abundant at the type locality on Garden Island in the Beaver Island group, Charlevoix County, Lake Michigan (Ehlers, 1945, pp. 73-80). The Garden Island formation is characteristically a dolomite which may be very sandy in places. Its patchy distribution in Michigan is similar to the occurrence of the Oriskany sandstone in southwestern Ontario. Over wide areas in Ontario post-Oriskany erosion has removed all of the Oriskany sandstone except for the grains of sand that had spilled into joint cracks in the underlying rock. It is suggested that the erratic distribution of the Garden Island formation is likewise due to erosion rather than nondeposition.

The Amherstburg formation was likewise eroded on the northeast flank of the Kankakee arch, but this truncation took place during the erosion interval following the deposition of the Amherstburg rocks. As a result Lucas formation directly overlies Bass Island dolomite in southwestern Michigan, beyond the zero thickness line of the Amherstburg (fig. 7).

Because of the erosional unconformity be neath the Detroit River group the underlying strata may differ both in age and lithology from one area to another, and even from well to well. This is especially noticeable where the Bass Island dolomite is beneath the Detroit River strata because of marked lithological differences in the Bass Island at dif- 


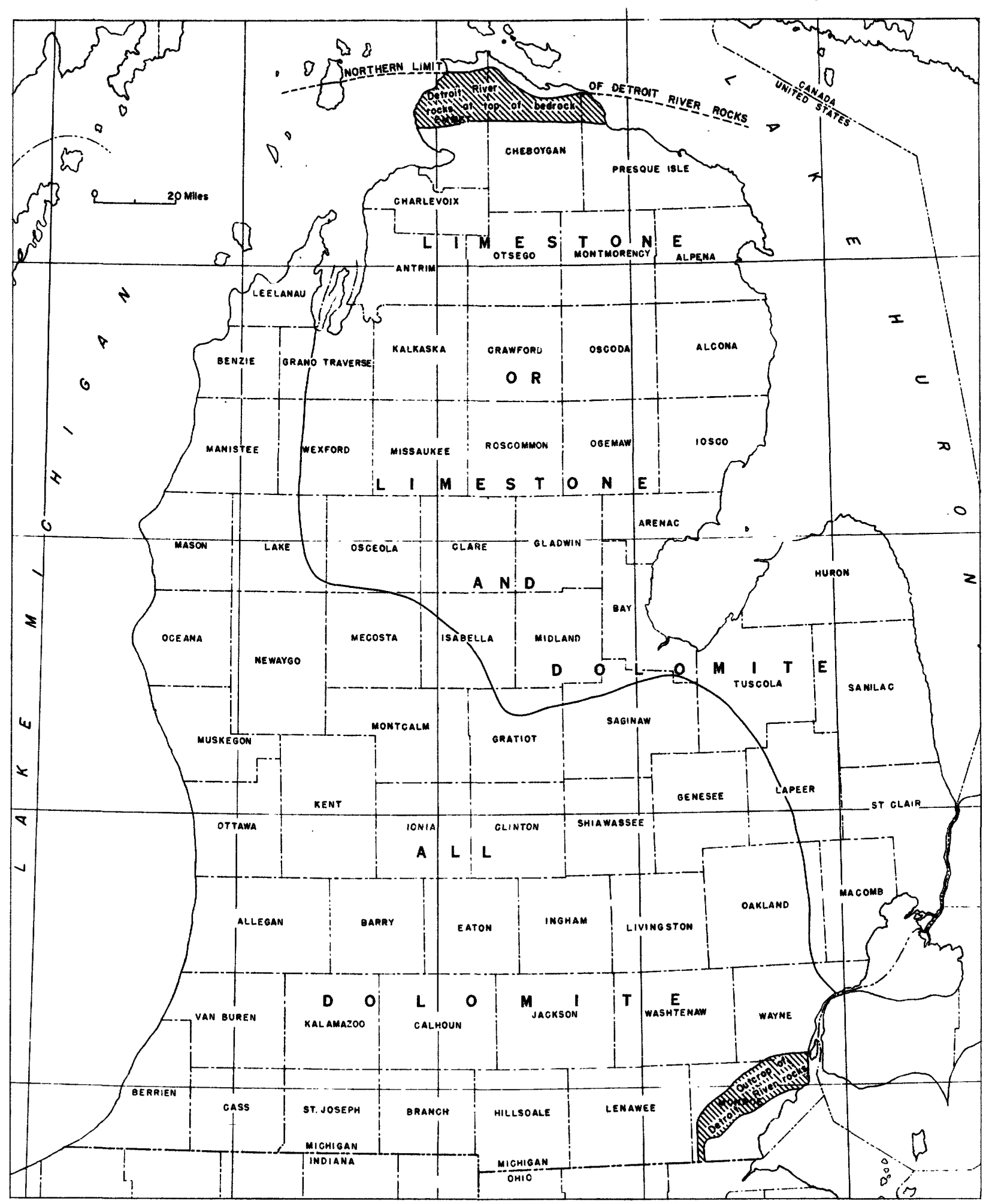

Figure 8. Limestone/dolomite facies map of Amherstburg formation. 
ferent stratigraphic levels. Wells in western and southwestern Michigan may penetrate pale yellowish dolomite, gray dolomite, bluish, highly argillaceous dolomite, or light green shale immediately below Detroit River rocks. The green shale was formerly considered by the writer to be "Sylvania equivalent" (1945a), but the Sherk well 1, sec. 21, T. 5 N., R. 10 W., Kent County, drilled through a shale that is apparently the same shale beneath Bois Blanc formation. This green shale is probably Bass Island in age, but it may have been deposited during Garden Island (Oriskany) time.

\section{STRUCTURAL GEOLOGY}

The regional structure of the Michigan Basin has been discussed by Newcombe (1933), Pirtle (1932), Smith (1937), and Lockett (1947). Figure 11 shows the structure of the Southern Peninsula of Michigan contoured with an interval of $500 \mathrm{ft}$ on the base of the Lucas formation. The most obvious structural feature is, of course, the Michigan Basin, but at this stratigraphic level the structural relief is only about 1 mile in 150 miles. Lockett (1947) points out that a baseball diamond, with a pitcher's mound eight inches high, has approximately the relative relief of the Michigan Basin.

Within the basin the major structural feature is the Howell anticline, a northwestward plunging fold on the southeast flank of the basin that is shown by well 17, cross section B-B'. The West $B$ ranch anticline in Ogemaw County, another large structure, is unusually well indicated by the contours on the base of the Lucas formation.

The presence of thick and relatively unyielding bodies of Sylvania sandstone member at the base of the Amherstburg formation resulted in some arching of the overlving strata due to differential compaction. Examples can be seen in cross sections $A-A^{\prime}, D-D^{\prime}$, and $G-G^{\prime}$.

Local structures in Michigan ordinarily are not discernible on a structure map of the basin contoured with an interval of $500 \mathrm{ft}$, but on figure 11 the $-4,000 \mathrm{ft}$ contour does disclose a domed area in northwestern Clare County. The wide spacing between the $-3,000$ and the $-3,500 \mathrm{ft}$ contours in southwestern Crawford County also denotes a local area of uplift.

In and near the belt of outcrop of the Detroit River group the rocks have subsided into collapse structures after leaching of the deeper salt of the Salina formation, especially during the erosion interval prior to the deposition of the Dundee for mation. These features are described in detail in a former report (1945c, pp. 121-154).

\section{GEOLOGIC HISTORY}

The area that is now the Southern Peninsula of Michigan had at least two distinct inundations and one downwarping of considerable magnitude during Detroit River time. However, the pertinent history of the Detroit River $g$ roup begins with Bass Island time. When the Bass Island sea withdrew, the area was covered with the youngest sedimentary rocks of the Bass Island dolomite. These late Silurian deposits were wide-spread. The Michigan Basin was not a topographic feature at this stage and the late Silurian sediments were deposited in a large area beyond the limits of the present structural basin. During the period of emergence prior to the encroachment of the earliest Devonian sea there was some erosion that removed the uppermost sediments of the Bass Island either completely or in part. By the time the earliest Devonian sea spread over the area that is now the Southern Peninsula of Michigan the topography was moderately rolling and rocks of different ages were exposed from place to place. The earliest Devonian sea was in Oriskany time, and in it the Garden Island formation was deposited. Emergence uplift followed and erosion removed the Garden Island formation everywhere in Michigan except for patches on Garden Island and elsewhere on the northern flank of the basin. In other areas, especially farther east in eastern Ohio and in Pennsylvania and New York, considerably more Oriskany sandstone was preserved. The postOriskany emergence and erosion interval was followed by widespread inundation by the Onondaga sea. In Michigan the Bois Blanc formation was deposited on the floor of this sea, covering both the remnants of the Garden Island formation and the twice-eroded Bass Island formation. Minor downwarping of the Michigan Basin took place at this time, resulting in preservation of a thicker Bois Blanc sequence north of Saginaw Bay. The withdrawal of the Onondaga sea from this area was followed by erosion of such magnitude that the Bois Blanc formation was completely removed from the flanks of the Kankakee and Findlay arches.

The areal geology at the time of the inundation by the earliest of the Detroit River sea (Amherstburg time) is shown in the pre-Detroit River geologic map (fig. 10). The feather edge of Bois Blanc formation varied widely in position from place to place owing to local differences in the depth of erosion. A downwarp along a northwestsoutheast axis from central Michigan across southeastern Michigan into northern Ohio permitted the entrance of marine waters which marked the beginning of Amherstburg time. The Sylvania sandstone member of the Amherstburg formation was deposited in this shallow trough in central and southeastern Michigan. It is postulated that wind-transported sand, probably from the area of outcrop of Cambrian sandstones and preCambrian quartzo,se rocks in Wisconsin, after drifting across the intervening emergent area, was blown into the early Amherstburg sea and thus preserved. No doubt surface weathering in the nearby emergent area contributed clastic 


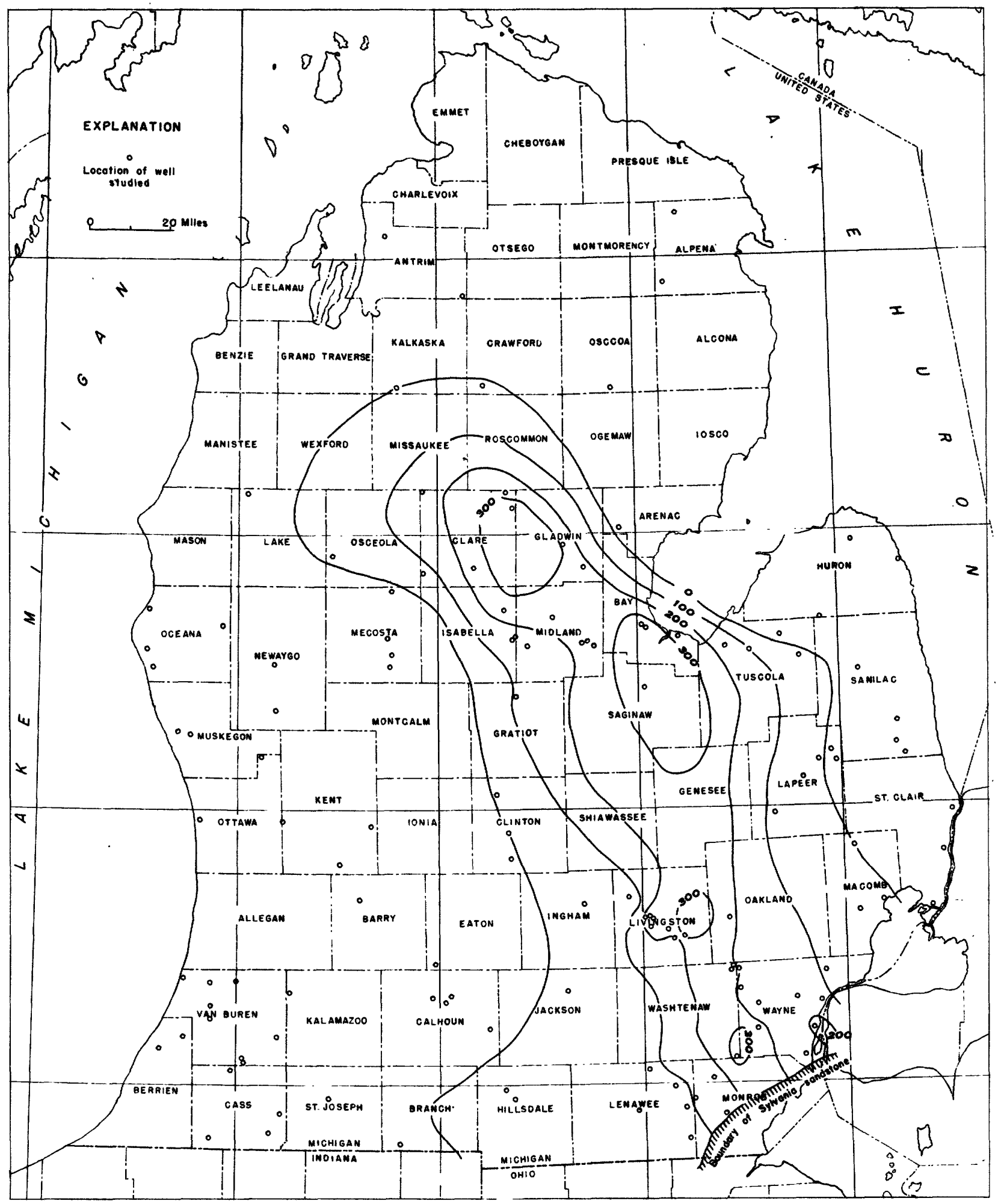

Figure 9. Thickness of Sylvania sandstone member of Amherstburg formation. 
grains of carbonate rock and chert to the eastward drifting quartz sands. Carbonate rock and chert were also deposited in the Sylvania sea (1) during intervals of nonsupply of quartz sand, and (2) on the leeward (eastern) side of the seaway beyond the area of sand deposition. Therefore the rocks of the Sylvania sandstone member of the Amherstburg contain some carbonate rock and chert as well as sand, and along the eastern edge of the Sylvania are some calcareous sediments of Sylvania age. The latter tends to be more siliceous than the younger Amherstburg strata, but are otherwise indistinguishable. The thickness map of the Sylvania (fig. 9) is confined to the sandstone phase.

An eolian origin of the Sylvania sandstone member of the Amherstburg formation was postulated by Sherzer and Grabau (1909), and Carman (1936) suggested a reworking of eolian sands by marine waters. But with these exceptions the tendency heretofore has been to consider the sand of the Sylvania as having accumulated by current action like modern beach and barrier sands, or like the famous oil-bearing "shoestring" sands of Kansas and Oklahoma. But the re are several strong arguments against this type of origin for the sand of the Sylvania. One is the size of the deposit of Sylvania. It exceeds $300 \mathrm{ft}$ in thickness and is from 50 to 75 miles wide, whereas beach or barrier sands, such as the Bartlesville or Burbank sands that were deposited in the Cherokee (Pennsylvanian) sea of the mid-continent, rarely reach two miles in width. Another argument is the isolation of the sand of the Sylvania from possible sources of supply. Perhaps the strongest evidence opposing ocean current deposition is the lack of any finer clastics (mud or clay) which invariably are associated with current-transported sands.

The evidence against the transportation of the sand of the Sylvania sandstone member of the Amherstburg formation by waters also to a considerable extent supports the theory of wind transportation. Comparable volumes of sand are winnowed clean and transported hundreds of miles by prevailing winds in areas of scant vegetation today. The Great Sand Dunes National Monument eastern San Luis Valley in Colorado contains enormous accumulations of clean sand carried from many miles to the west and dropped where the winds are slowed by the Sangre de Cristo Mountains which form the valley wall to the east. If there were a lake or sea covering eastern San Lui.s Valley the marching sands would have been trapped somewhat in the manner suggested for the Sylvania.

Detroit River time precede that of the earliest known forests and the land was probably almost completely bare of vegetation, so the prevailing westerlies could pick up the abundant quartz sand released from the weathering of the Cambrian and Lower Ordovician sandstones that cropped out in eastern Wisconsin and from decomposing and disintegrating pre-Cambrian granites still farther west, and transport the grains eastward until they sank into the waters of the early Amherstburg (Sylvania) sea.

Later in Amherstburg time the sea spread more widely and eventually covered all the area of the Southern Peninsula as well as adjacent areas. Carbonate rocks were the main deposits in the expanded seaway, but during the earliest phases sand present on the submerging surface was mixed with the carbonate deposits so that a sandy limestone or dolomite was formed. The water was probably not very deep at any place, and brief emergences may have taken place which permitted the eastward movement of wind driven sands (Filer) from the outc rop area of the older sandstones in Wisconsin. A relatively moderate amount of sagging took place in the Michigan Basin dur ing the later part of Amherstburg time and more than $300 \mathrm{ft}$ of carbonate rock accumulated after deposition of the Sylvania sandstone member. The deepest part of the basin during this interval was in the area that is between southeastern Roscommon and east central Tuscola Counties, which is parallel to, but northeast of, the axis of the Sylvania downwarp in central Michigan. Throughout most of Amherstburg time after deposition of the Sylvania the concentration of calcium sulfate in the sea water was close to the saturation point and small amounts of anhydrite were precipitated from time to time.

Amherstburg deposition closed with complete emergence of the area. Not only did the sea withdraw, but the area was elevated sufficiently for active erosion to take place. The Amherstburg sediments were removed from the Kankakee arch by erosion, but the erosion was of less magnitude than that which had previously re moved the Bois Blanc formation from the same area. The zero thickness line of the Amherstburg in figure 7 shows the extent of erosion basinward. In south-central Michigan (Hillsdale County) the carbonate rocks were entirely removed and the underlying Sylvania sandstone member exposed.

During this period of emergence sand dunes again progressed eastward across the land surface into what is now western and central Michigan. With the submergence of the land beneath the Lucas sea these bodies of sand, some of them completely isolated, were trapped and became sandstone lenses in the Richfield member of the Lucas. One of these isolated dunes is in southwestern Clare County, where the "Freer sand" lens is more than $50 \mathrm{ft}$ thick in one well and absent in two offset wells. The earliest Lucas sea was widespread, extending beyond the present limits of the Michigan Basin, especially across the axis of the Findlay arch into northern and northeastern Ohio. During this time the Lucas and Anderdon formations of the 


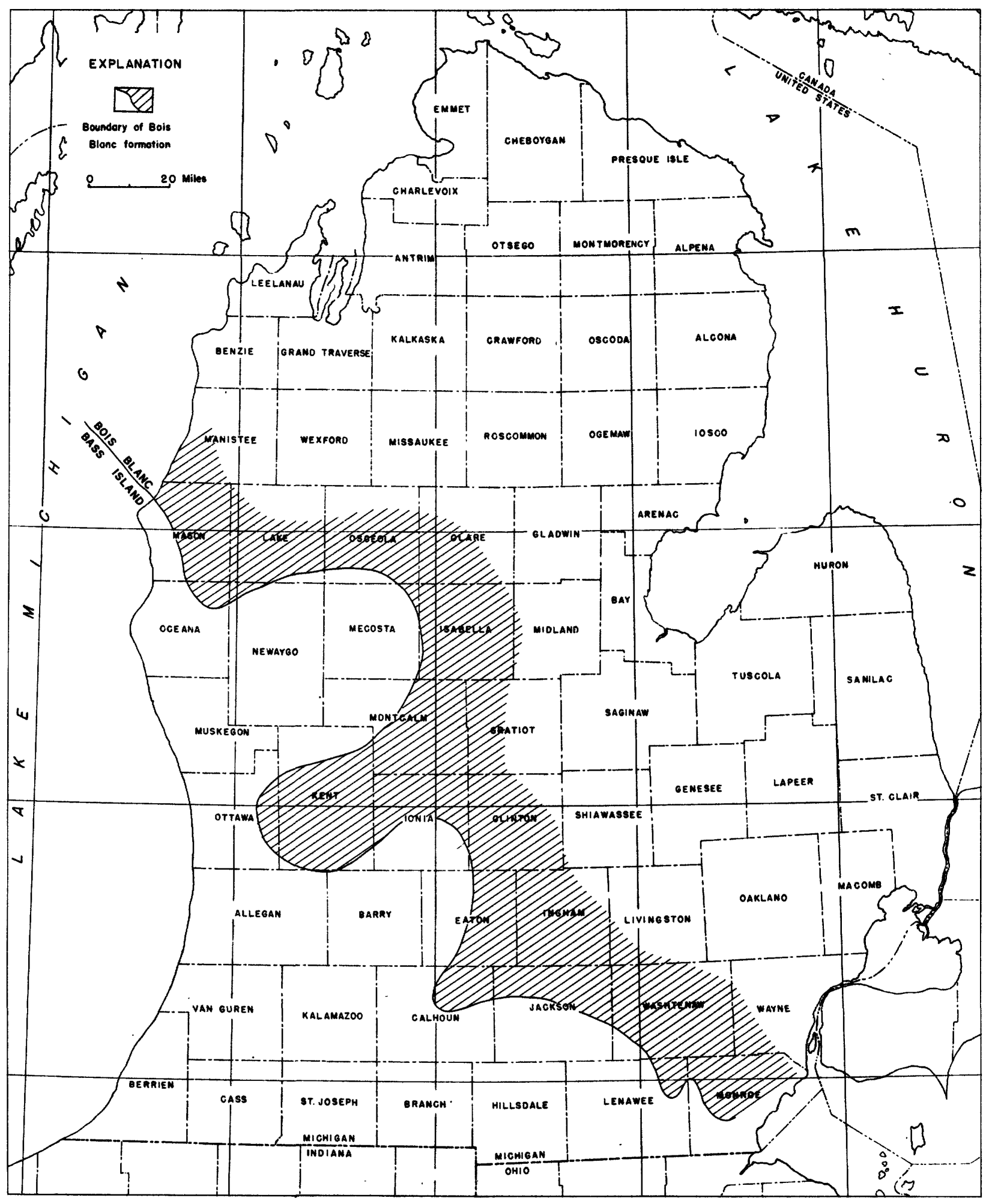

Figure 10. Boundary of the Bois Blanc formation in southwestern Michigan. South of this line the Detroit River group is directly on rocks of Bass Island age. 


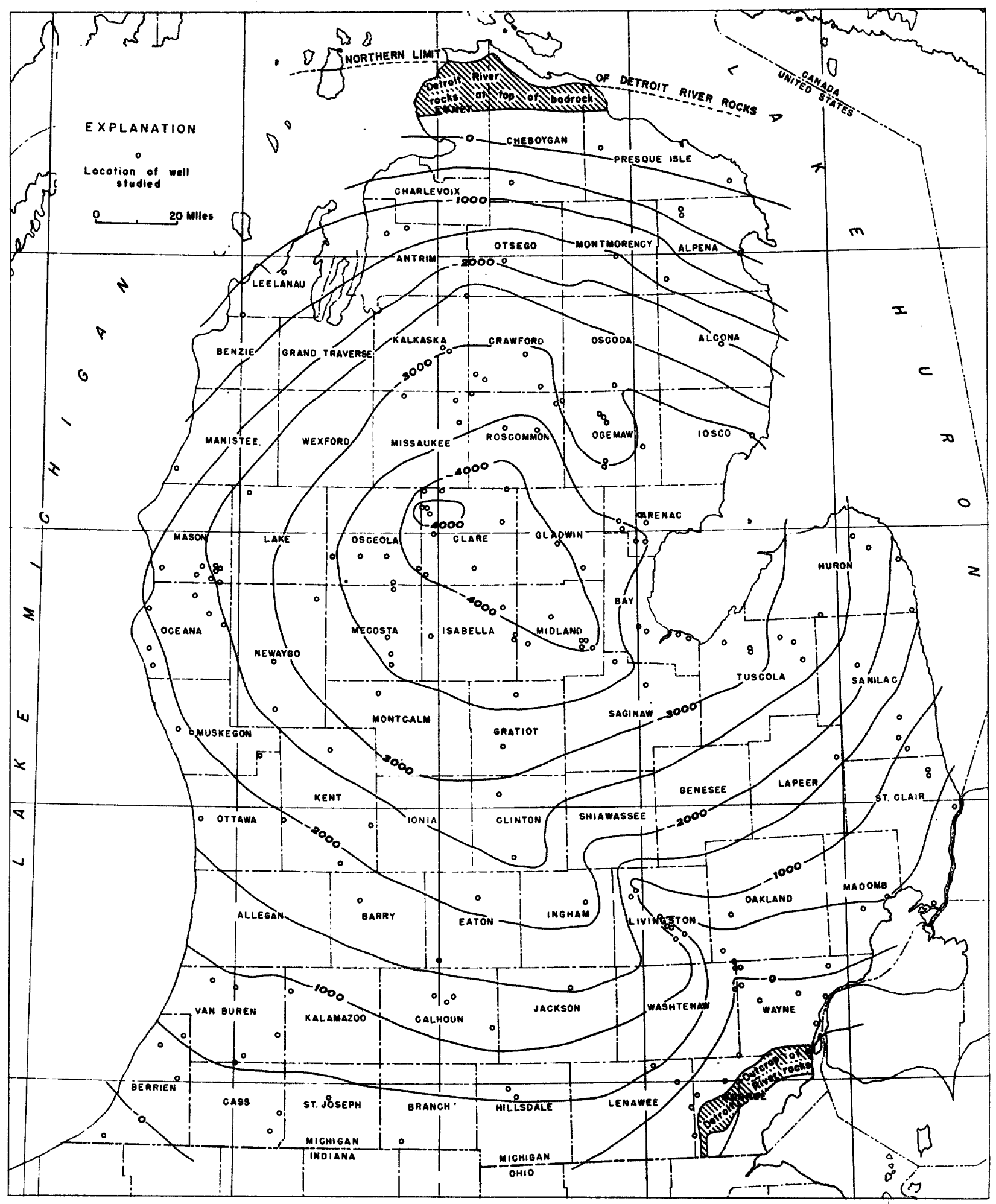

Figure 11. Structure contour map of Southern Peninsula of Michigan contoured on base of Lucas formation. 
present Ohio-Michigan outcrop area were deposited. Far out from shore, and away from the freshening effect of entering streams, the waters were saturated with calcium sulfate and layers of anhydrite were periodically precipitated. The first major downwarp of the Michigan basin since the evaporite deposition of the Salina formation followed the deposition of the earliest Lucas sediments and the connection with open water across the Findlay arch was destroyed by emergence. Within the land-locked Lucas sea which covered the Michigan Basin the continued evaporation resulted in the precipitation of large quantities of anhydrite. When the sea had shiunk until it covered only a part of the northern half of the Southern Peninsula, salt precipitation began and continued intermittently until more than $400 \mathrm{ft}$ of salt was deposited. The source of this salt was probably the salt measures of the Salina formation which were being leached at this time by waters percolating through the outcropping layers higher on the flanks of the basin. Studies made by the writer (1945c) in the Mackinac Straits area have shown that an enormous quantity of salt was leached from the Salina exposed along the north rim of the basin during Middle Devonian time. Before deposition of the Dundee formation, collapse into salt caves of the Salina took place on a regional scale. The leaching of salt at this time was probably much more extensive than just along the north rim; collapse features at the south side of the Michigan Basin indicate solution activity there also. The probable presence of an outer topographic rim, made by the same resistant limestone of the Niagara group that form the Niagara escarpment today, gives some further support to the theory that the great volume of salt leached from the Salina during the middle Devonian time was washed into the desiccating late Lucas sea where it was precipitated when this land-locked body of water had shrunk until it occupied only the deepest part of the basin.

The downwarping during later Lucas time continued until a total of more than 1,000 ft of carbonate rock, anhydrite, and salt had been deposited in the center of the basin. Meanwhile, according to the Ehler's hypothesis, with the emergence of Findlay arch, sediments of Columbus age were deposited on top of the older Lucas sediments southeast of the arch. No definite break has been found at the outcrop in northern Ohio between Detroit River and Columbus strata, and it is probable that sea did not withdraw but was made more shallow by the emergence of the Findlay arch. The Columbus sea probably did not extend into the Michigan Basin where the late Lucas sea was desiccating. If this theory is correct, the Columbus limestone is the equivalent in time of the younger evaporites, including the salt, in upper part of the Lucas of the central part of the Michigan Basin.

Paul Weaver, Gulf Oil Corp., Huston, Texas, in an address at the University of Michigan, Jan. 14,1949 , pointed out the much higher rate of de- position of carbonate rock. Consequently a thic $k$ evaporite section could be accumulating while a very much thinner limestone succession was being deposited elsewhere.

An alternative possible explanation for salt deposition in Lucas time is that the Columbus sea did spill across the Findlay arch occasionally, thereby adding more salt to the evaporating waters occupying the Michigan Basin. This explanation, which is the bar theory of salt, concentration, is applied rathe $r$ generally to explain the salt beds deposited earlier in Salina time in the Michigan Basin on a much greater scale.

Before the close of Lucas time the waters freshened somewhat, possibly due to increased rainfall, salt precipitation ceased, and anhydrite deposition decreased. At the same time carbonate rock deposition increased in relative abundance. The basin was filled with sediment, losing its identity as a topographic feature. The Lucas and Columbus seas withdrew and an interval of emergence and erosion followed. Some sand was carried out over the emergent lands, especially in Ontario and eastern Michigan. The distribution of this sand strongly suggests a source in Ontario rather than in Wisconsin. Submergence by the Dundee and Delaware sea followed, and the sands became incorporated in the basal parts of Dundee and Delaware strata. This sea was widespread, covering a considerable area beyond the boundaries of the Michigan Basin. Dundee and Delaware deposition was followed by the deposition of the Rogers City formation. Emergence followed the deposition of Dundee and Rogers City strata and subsequent erosion stripped these rocks from the southwestern corner of Michigan and again exposed Detroit River group at the surface. The truncated layers of the formations of the Detroit River were later covered by deposits of the Traverse sea. Additional downwarpings of the basin, which were minor in intensity as compared with that of Lucas time, have further increased the basin structure. Folding continued intermittently throughout the sedimentary history of the basin but reached a climax during the pre-Pennsylvanian emergence. Pre-glacial erosion exposed the circular band of outcrop of the Detroit Rive $\mathbf{g}$ roup between the center and the periphery of the Michigan Basin, but glacial and post-glacial deposits, and the waters of the Great Lakes, have masked most of these exposures except for a few in southeastern Michigan, northern Ohio, and southwestern Ontario.

\section{ECONOMIC GEOLOGY}

Oil and gas (Grant and Eddy, 1949; Cohee and Martin, 1948). Reservoirs in rocks of the Detroit River $\mathbf{g}$ roup have yielded about one- 


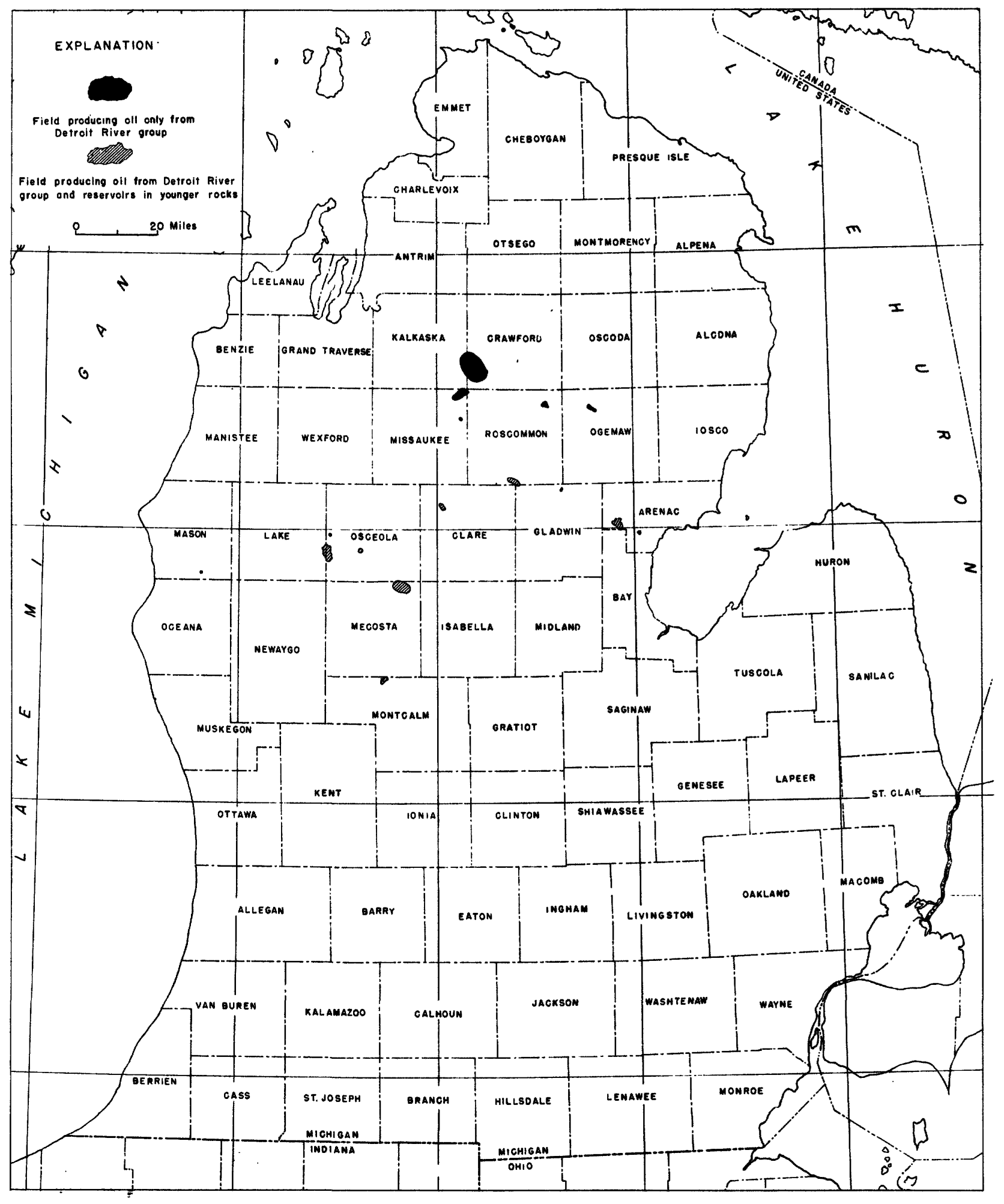

Figure 12. Oil producing fields. 
eighth of the total production of oil and gas in Michigan to date. As no appreciable amount of oil was produced from the Detroit River before the year 1940, when the Reed City field was discovered, the yield in recent years has been considerable and has called attention to future oil prospects in Detroit River strata.

All the oil and gas so far produced commercially from Detroit River group has come from the Lucas formation and mostly from dolomites within that formation. The Sylvania sandstone member of the Amherstburg formation has yielded good "showings" of oil in several wells (Landes, 1945a) but no production as yet. Oil found in sandstone in Mason County originally believed to have been from the Sylvania sandstone member, is actually from the sandstone of the Richfield member of the Lucas according to Enyert (1949). The Filer sandstone lentil, and the limestones and dolomites of the Amherstburg, so far have been found barren of oil or gas in commercial volume.

The reservoirs within the Lucas formation discovered to date are either near the top or near the bottom of the formation. The upper reservoirs lie in the "Reed City zone", so-called because it is the source of oil from the Detroit River group in the Reed City field in Osceola County. The lower zone is named the "Richfield," after the Richfield pool in Roscommon County. All of the "Reed City zone" production comes from dolomite layers lying within the uppermost $100 \mathrm{ft}$ of the evaporite unit, and the largest yields come from rocks from 20 to $50 \mathrm{ft}$ below the base of the Dundee formation. Some Michigan petroleum geologists include the "Reed City zone" in the lower part of the Dundee.

The "Richfield zone" occupies the lowest part of the Lucas formation. In the fields with important production from this zone the reservoirs are porous dolomite layers scattered through a section nearly $100 \mathrm{ft}$ thick between the lowest thick anhydrite bed and the top of the Amherstburg formation. Interconnecting fractures may be the reason for much of the porosity of the dolomite of the Richfield member. Leading fields (fig. 12) are the Beaver Creek, East Norwich, Enterprise, and Richfield. Others include the Winterfield, Rose City, Fork, and Cedar fields. Minor production has been obtained from sandstones in the Richfield member in the Freer pool of Clare County and the Logan field of Mason County. In the small Akron field in northwestern Tuscola County the producing zone is a series of porous dolomite beds lying, in part at least, above the lowest anhydrite bed in the Lucas formation. The oil occurrences in the Atlanta area of Montmorency County are also in dolomite interbedded with anhydrite. Lindberg (oral communication) believes that Tuscola-Montmorency reservoirs are above and distinct from the "Richfield zone."

In exploring for oil in the basal part of the Lucas formation it has been the custom to drill until either oil was found or the "Black Lime" of the underlying Amherstburg formation was penetrated. Unfortunately the presence of "false" black limestone beds in the Lucas above the Richfield member has led to the abandonment of several wells in Roscommon and Tuscola Counties before the possible producing beds were penetrated.

The oil fields so far discovered in the Detroit River group are anticlinal accumulations. The dolomite zone of the Richfield member of the Lucas formation appears to have greater lateral continuity of porosity than the sandstone of the Richfield member. The latter may consist of a series of discontinuous lenses, each one of relatively small size. The same is probably true of the Filer sandstone lentil of the Amherstburg formation. The lenses of the Sylvania sandstone member of the Amherstburg are more extensive, but are very likely also discontinuous. Exploration of this zone to date has been disappointing. However, most wells penetrating the Sylvania sandstone member in the central part of the basin have been off structure.

It is reasonable to assume that many new fields in the Detroit River $g$ roup will be dis covered by exploring the Detroit River sequence of rock from top to bottom on anticlines. Stratigraphic traps, due to porosity pinch out in the dolomite zones, and also due to sand lenticularity, are additional possibilities.

Salt. - Salt in the Detroit River group has been exploited by the brine well method in Manistee County since 1881 and in Mason County since 1886 . These salt producing areas are close to the western edge of the salt deposit of the Detroit River (fig. 5) In these areas the salt is thinnest, but it is also closest to the surface and is adjacent to water transportation. No attempt has been made to mine salt of the Detroit River. In the center of the deposit the aggregate thickness exceeds $400 \mathrm{ft}$. The reserve, although small in comparison with that of the deeper salt in the Salina formation, is enormous in terms of annual world production.

\section{REFERENCES CITED}

Carman, J.E., 1936, Sylvania sandstone of northwestern Ohio: Geol. Soc. America Bull., vol: 47, pp. $253-265$.

Cohee, G. V., and Martin, H. M. , 1948, A summary of the stratigraphy of the Southern Peninsula of Michigan: Michigan Geol. Soc. Rept., pp. 7-8.

Cohee, G. V., and Underwood, L. B. , 1945 , Lithology and thickness of the Dundee formation and the Rogers City limestone in the Michigan Basin: U.S. Geol. Survey Oil and Gas Inves tigations Preliminary Map 38. 
Cooley, G. A. , 1947, Insoluble residues of Detroit River and Dundee formations: (Univ. Michigan, unpublished thesis).

Cooper, G. A., and others, 1942, Correlation of the Devonian sedimentary formations in North America: Geol. Soc. America Bull., vol. 53, p. 1754.

Ehlers, G. M. , 1945, Geology of the Mackinaw Straits region: Michigan Geol. Survey Pub. 44, pp. $111-116$.

1950, Revised classification of the Middle Devonian Detroit River group [abstract]; Geol. Soc. America Bull., vol. 61, no. 12, pt. 2, pp. 1455-1456.

Enyert, R. L., 1949, Middle Devonian sandstones of the Michigan Basin: (Univ. Michigan, unpublished doctoral thesis; to appear in Am. Assoc. Petroleum Geologists Bull.).

Grabau, A. W. , and Sherzer, W. H., 1910, The Monroe formation of southern Michigan and adjoining regions: Michigan Geol. Survey Pub. 2.

Grant, R. P., and Eddy, G. E., 1949, Prospects for and results of drilling beyond proven areas and to deeper zones in the Michigan Basin: Oil and Gas News, vol. 30, June 17.

Landes, K. K. , 1945a, Geology and oil and gas possibilities of Sylvania and Bois Blanc formations in Michigan: U.S. Geol. Survey Preliminary Map 28.

1945b, The Salina and Bass Island rocks of the Michigan Basin: U.S. Geol. Survey Preliminary Map 40.

1945c, Geology of the Mackinaw Straits region and subsurface geology of the northern Southern Peninsula: Michigan Geol. Survey Pub. 44.
Lane, A. C. , Prosser, C. R., Sherzer, W. H. and Grabau, A. W., 1909, Nomenclature and subdivision of the upper Siluric strata of Michigan, Ohio, and western New York: Geol. Soc. America Bull., vol. 19, pp. 553566.

Lockett, J.R., 1947, Development of structures in basin areas in northeastern United States, Am. Assoc. Petroleum Geologists Bull., vol. 31, pp. $429-446$.

Newcombe, R.B., 1933, Oil and gas fields of Michigan: Michigan Geol. Survey Pub. 38

1929 [1930], Interpretation of recent discoveries in the salt-bearing rocks of Michigan: Michigan Acad. Sci., Arts, and Letters, vol. 12, pp. 239-250.

Pirtle, G. W. , 1932, Michigan structural basin and its relationship to surrounding areas: Am. Assoc. Petroleum Geologists Bull., vol. 16, pp. $145-152$.

Saunders, J. M. , 1948, Lithology and insoluble residues of a core from the Detroit River group: (Univ. Michigan, unpublished thesis).

Sherzer, W. H. , and Grabau, A. W., 1909, The Sylvania sandstone, its distribution, nature and origin: Michigan Geol. Survey Pub. 2, chapter 3, pp. 61-86.

Smith, R. A., 1937, 1938, Some new aspects of the Michigan Basin [abstract]: Proc. Geol. Soc. America, p. 326.

Tharp, Marie, 1944, Subsurface studies of the Detroit River series: (Univ. Michigan, unpublished thesis).

Wellman, D. D. , 1937, Insoluble residues of Dundee and Detroit River (Upper Monroe) formations of Central Michigan: Am. Assoc. Petroleum Geologists Bull. vol. 21, pp. 317332.

WELLS USED IN CROSS SECTIONS

\begin{tabular}{|c|c|c|c|c|c|}
\hline \multirow{2}{*}{$\begin{array}{l}\text { No. in } \\
\text { sections }\end{array}$} & \multirow{2}{*}{ County } & \multirow[b]{2}{*}{ Company, farm, and number } & \multicolumn{3}{|c|}{ Location } \\
\hline & & & Section & Township & Range \\
\hline $\begin{array}{r}5 \\
6 \\
7 \\
8 \\
9 \\
10 \\
11 \\
12 \\
13 \\
14 \\
15 \\
16 \\
17 \\
18 \\
19 \\
20\end{array}$ & $\begin{array}{l}\text { Berrien } \\
\text { Berrien } \\
\text { Van Buren } \\
\text { Kalamazoo } \\
\text { Barry } \\
\text { Gratiot } \\
\text { Midland } \\
\text { Ogemaw } \\
\text { Oscoda } \\
\text { Alpena } \\
\text { Alpena } \\
\text { Presque Isle } \\
\text { Antrim } \\
\text { Antrim } \\
\text { Clare } \\
\text { Midland } \\
\text { Livingston } \\
\text { Livingston } \\
\text { Washtenaw } \\
\text { Wayne }\end{array}$ & 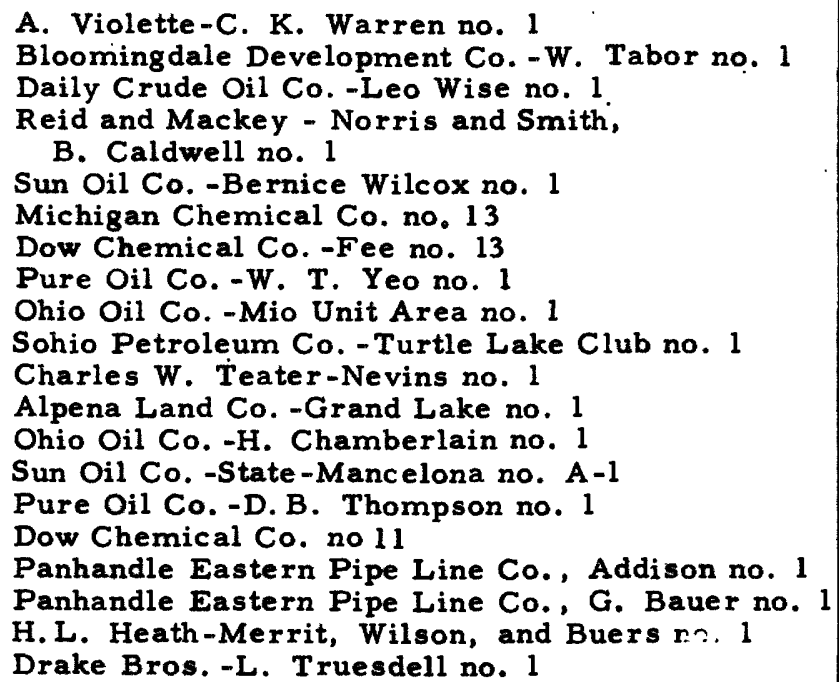 & $\begin{array}{r}8 \\
33 \\
26 \\
\\
32 \\
5 \\
24 \\
19 \\
2 \\
30 \\
9 \\
18 \\
8 \\
14 \\
36 \\
3 \\
20 \\
11 \\
25 \\
1 \\
25\end{array}$ & $\begin{array}{r}8 S \\
5 S \\
3 S \\
1 S \\
3 N \\
12 N \\
14 N \\
21 N \\
25 N \\
29 N \\
32 N \\
33 N \\
31 N \\
29 N \\
20 N \\
14 N \\
3 N \\
2 N \\
1 S \\
2 S\end{array}$ & $\begin{array}{c}20 W \\
17 W \\
13 W \\
12 W \\
9 W \\
3 W \\
2 E \\
2 E \\
3 E \\
5 E \\
6 E \\
8 E \\
8 W \\
5 W \\
3 W \\
2 E \\
3 E \\
5 E \\
7 E \\
8 E\end{array}$ \\
\hline
\end{tabular}




\begin{tabular}{|c|c|c|c|c|c|}
\hline \multirow{2}{*}{$\begin{array}{l}\text { No. in } \\
\text { sections }\end{array}$} & \multirow[b]{2}{*}{ County } & \multirow[b]{2}{*}{ Company, farm, and number } & \multicolumn{3}{|c|}{ Location } \\
\hline & & & Section & Township & $\overline{\text { Range }}$ \\
\hline $\begin{array}{l}24 \\
25 \\
26 \\
27 \\
28 \\
29 \\
30 \\
31 \\
32 \\
33 \\
34 \\
35 \\
36 \\
37 \\
38 \\
39 \\
40 \\
41 \\
42 \\
4 \\
43 \\
44 \\
45 \\
46 \\
47 \\
48 \\
49 \\
50 \\
51 \\
52 \\
53 \\
54 \\
55 \\
56\end{array}$ & $\begin{array}{l}\text { Wayne } \\
\text { Berrien } \\
\text { Van Buren } \\
\text { St. Joseph } \\
\text { Hillsdale } \\
\text { Lenawee } \\
\text { Washtenaw } \\
\text { Wayne } \\
\text { Oceana } \\
\text { Oceana } \\
\text { Mecosta } \\
\text { Midland } \\
\text { Bay } \\
\text { Tuscola } \\
\text { Huron } \\
\text { Cass } \\
\text { Van Buren } \\
\text { Muskegon } \\
\text { Oceana } \\
\text { Mason } \\
\text { Leelenau } \\
\text { Leelenau } \\
\text { Leelenau } \\
\text { Monroe } \\
\text { Wayne } \\
\text { Macomb } \\
\text { St. Clair } \\
\text { Huron } \\
\text { Iosco } \\
\text { Manistee } \\
\text { Lake } \\
\text { Osceola } \\
\text { Clare } \\
\text { Clare } \\
\text { Arenac } \\
\text { Huron }\end{array}$ & 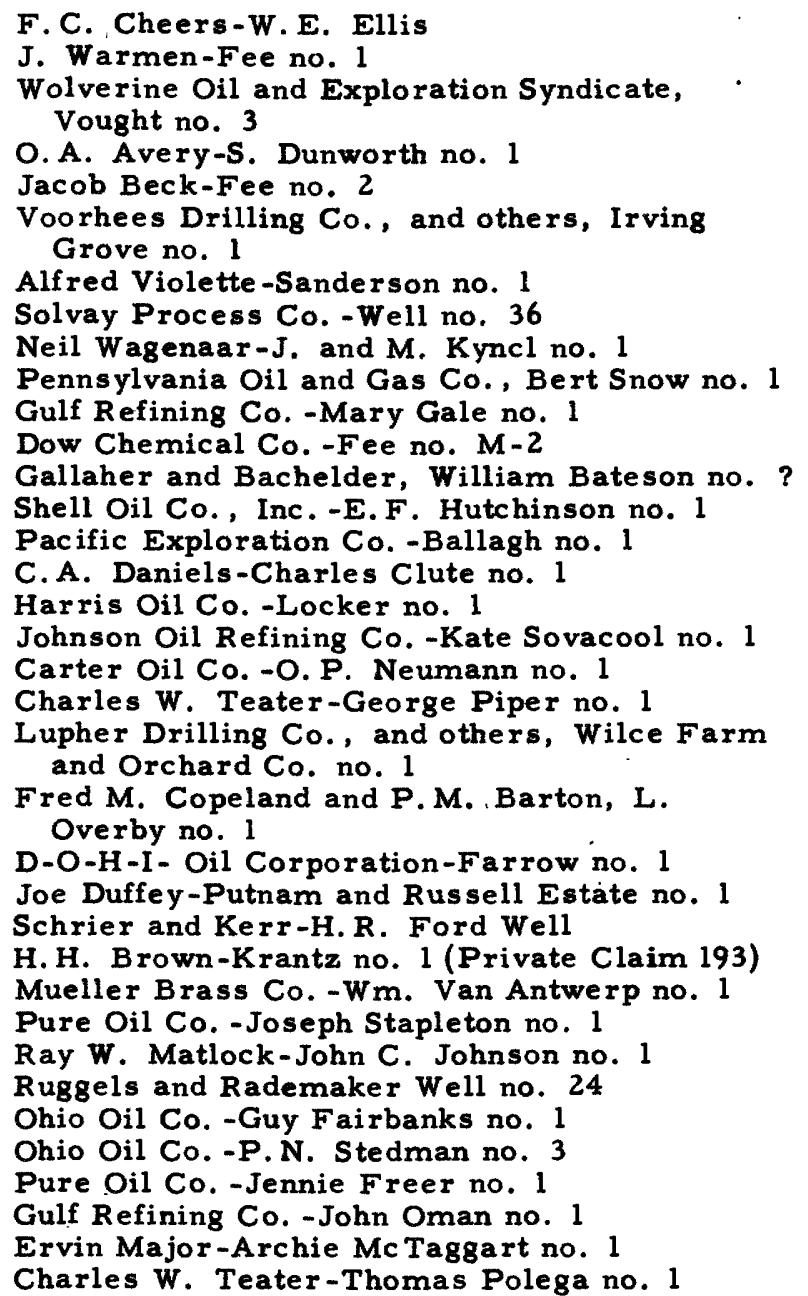 & $\begin{array}{r}35 \\
34 \\
\\
32 \\
13 \\
15 \\
\\
8 \\
26 \\
26 \\
35 \\
23 \\
3 \\
27 \\
2 \\
21 \\
32 \\
2 \\
13 \\
2 \\
21 \\
18 \\
\\
34 \\
\\
5 \\
13 \\
5 \\
22 \\
9 \\
22 \\
1 \\
12 \\
11 \\
29 \\
18 \\
8 \\
26 \\
27\end{array}$ & $\begin{array}{r}4 S \\
3 S \\
4 S \\
6 S \\
6 S \\
5 S \\
4 S \\
2 S \\
16 N \\
15 N \\
14 N \\
14 N \\
14 N \\
14 N \\
15 N \\
7 S \\
1 S \\
10 N \\
14 N \\
17 N \\
28 N \\
\\
29 N \\
8 S \\
6 S \\
2 S \\
3 N \\
6 N \\
17 N \\
22 N \\
21 N \\
20 N \\
18 N \\
17 N \\
17 N \\
19 N \\
18 N\end{array}$ & $\begin{array}{c}10 E \\
17 W \\
14 W \\
11 W \\
3 W \\
4 E \\
7 E \\
11 E \\
18 W \\
15 W \\
8 W \\
2 E \\
4 E \\
10 E \\
12 E \\
13 W \\
15 W \\
17 W \\
18 W \\
17 W \\
14 W \\
12 W \\
5 E \\
7 E \\
10 E \\
14 E \\
17 E \\
15 E \\
8 E \\
17 W \\
14 W \\
10 W \\
6 W \\
4 W \\
3 E \\
13 E\end{array}$ \\
\hline
\end{tabular}

